\title{
الاستدلال اللغوي عند الأصوليين: مقاربة تداولية
}

*يحيى رمضان

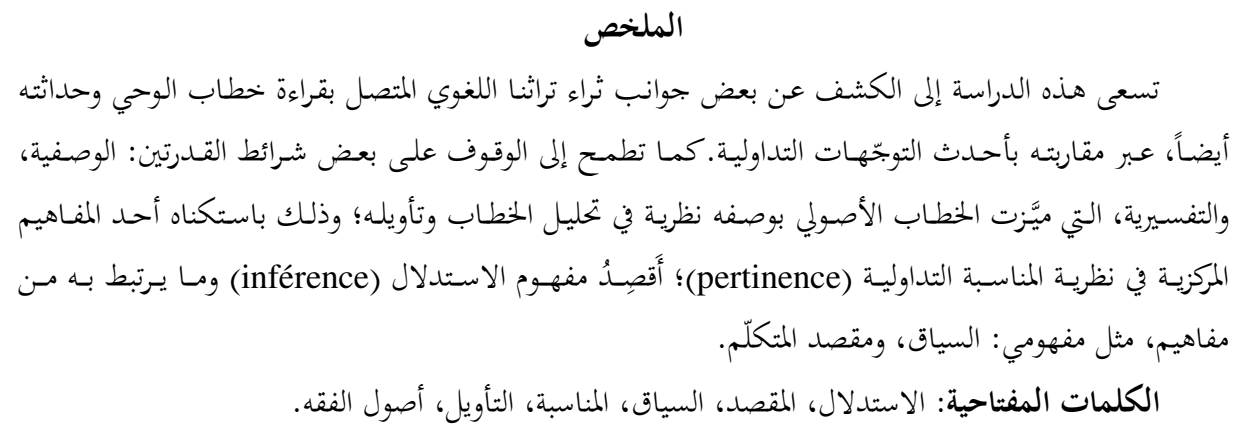

\section{Linguistic Inference of Scholars of the Usul : Pertinence Approach}

Abstract

This study uses recent pertinence trends to demonstrate some aspects of richness in our linguistic legacy pertaining to the discourse of Divine Revelation and its temporality, and to reveal the descriptive and interpretive capabilities of the Usuli discourse (discourse of principles of jurisprudence) as being a theory in discourse analysis and interpretation. This purpose has been achieved through one of the central concepts of the theory of pertinence; i.e., the concept of inference and other relevant concepts such as context and intention.

Keywords: inference, intention, context, pertinence, interpretation, principles of jurisprudence

$$
\begin{aligned}
& \text { " دكتوراه الدولة في مناهج تحليل الخطاب، أستاذ مكوّن بالمركز الجهوي لمهن التربية والتكوين، مكناس- المغرب. البريد } \\
& \text { ramdane2y@yahoo.fr الإلكترويني }
\end{aligned}
$$

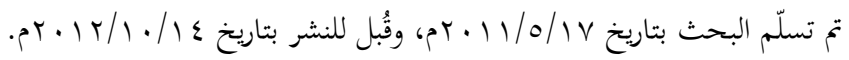




\section{مقدمة:}

في سـياق الاهتمـام بتجديــ النظـر في المـوروث الإسـلامي الـذي انشـلـ بـالقراءة

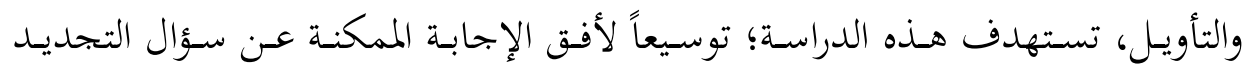

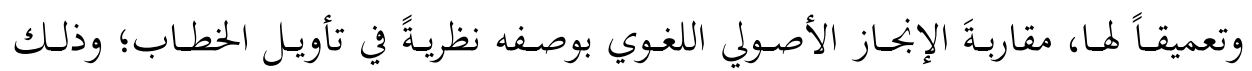

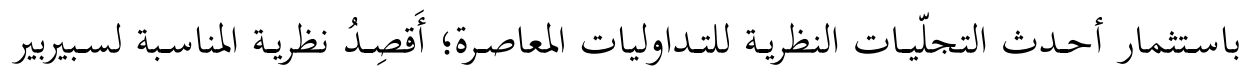

\section{. (Wilson) (Sperber)}

يتمثَّل هـدف هـذه الدراسـة الرئيس في محاولـة اقـراح صـياغة بنـاء نظـري منسـهم

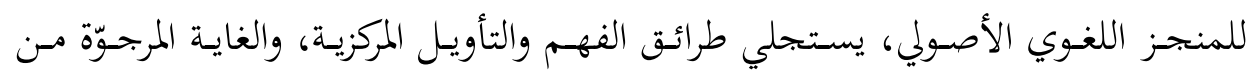

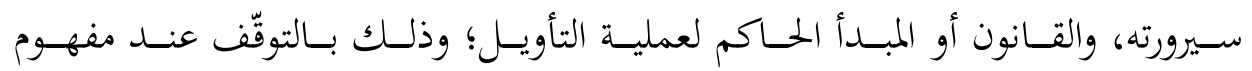

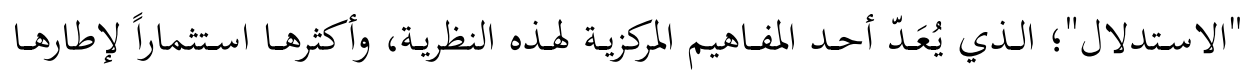

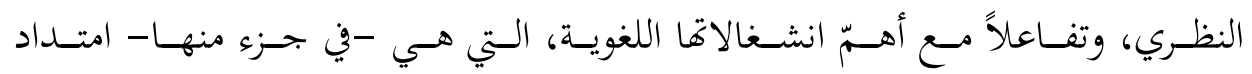
للانشغالات اللغوية التداولية بعامة.

كلّ ذلك في أفق مقـارين يَتغيّا إدراك التقاطعـات النظريـة بـين الإبحازين: الأصـولي،

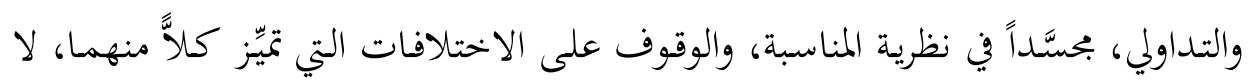

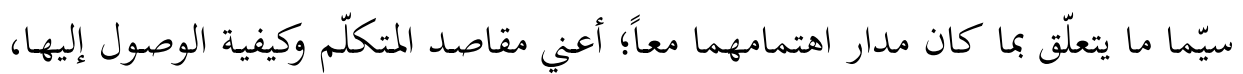
ودور الاستدلال في ذلك، وطبيعة هذا الاستدلال ومكوّناته.

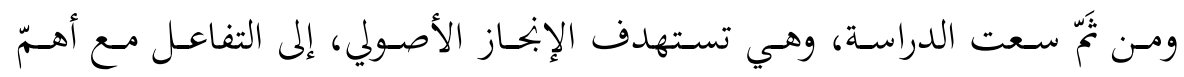

الانشغالات اللغوية المعاصرة التي ميَّزت التوجّه التداولي لنظرية المناسبة، خاصِّة مـا تعلّق

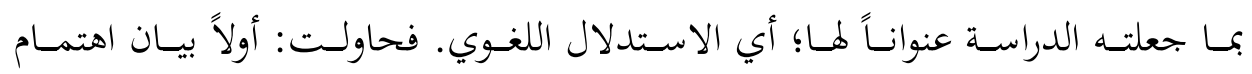
الأصوليين بالاستدلال بوصفه مكوّناً أساسيّاً من مكوّنات العملية التأويلية. وثانياً إظهار

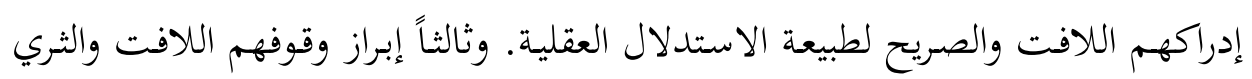
عند تمييز الاستدلال اللغوي عن غيره من أنواع الاستدلالات الأخرى التي كانت مدار

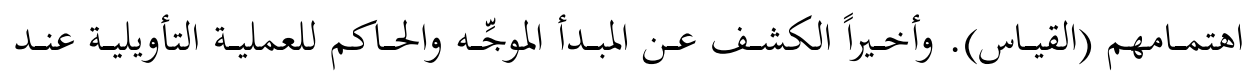


الأصـوليين، وبيـان طبيعته العقلانية، هذا المبـدأ الذي رأت الدراسة أن مـا سمّاه الشـاطبي بمقصد الفهم هو التجسيد الأكمل له.

وإذ تحصـر الدراسـة اهتمامهـا - في هـذه المقاربـة- بنظريـة المناسـبة دون غيرهـا مـن

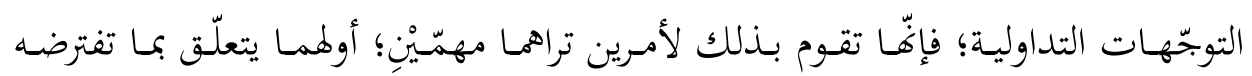
(الدراسة) من اتساع مدى التقاطعات بين هذه النظرية والإنحاز الأصولي. وثانيهما يتعلّق

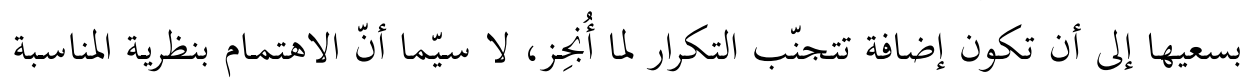

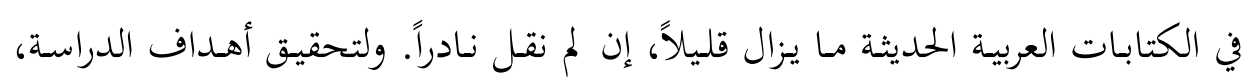

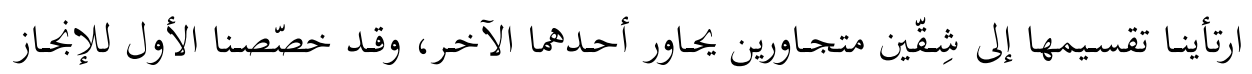

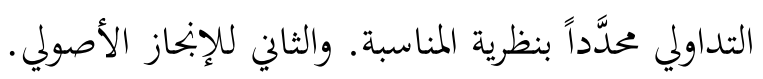
وقد يكون مفيداً، قبل الشروع في ما نرومه، الإشارة إلى أنّ الكتابات العربية المعاصرة التي قاربـت التراث العـربي الإسـلامي مـن خهالال مفهـوم الاستـلال، متسـلِّحةً بالإبحـاز

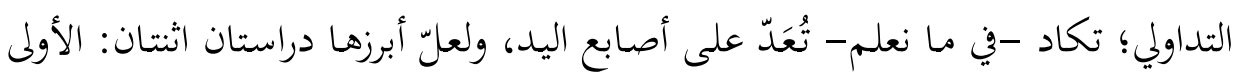
للدكتور طه عبد الرحمن، وقد ضمَّنها كتابه "اللسان والميزان أو التكوثر العقلي." "إبع والثانية

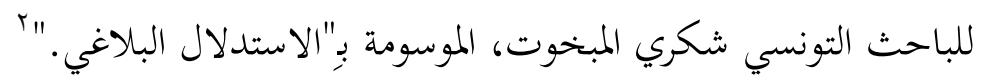

تندرج مقاربة طه عبد الرحمن في إطار انشغالٍ فكري وفلسفي عامّ، فُيمِن عليه فكرة

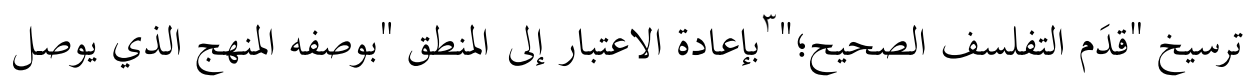

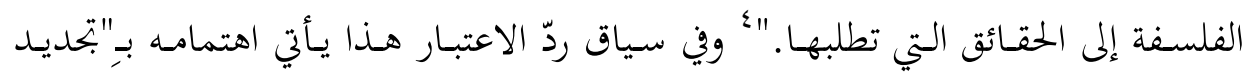

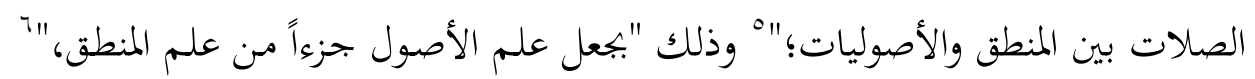
على عكس ما قام به المتقدِّمون الذين جعلوا من المنطق مقدِّمة لعلم الأصول.

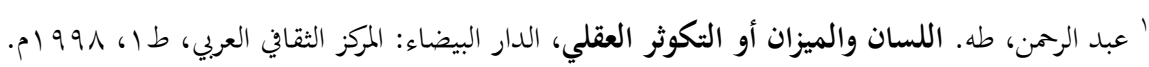

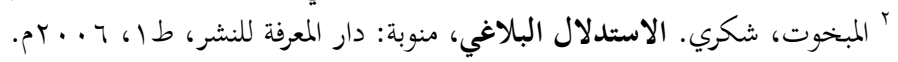

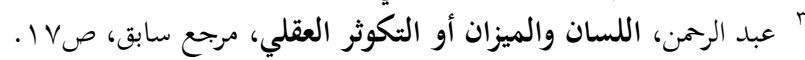

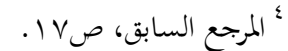

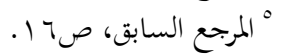

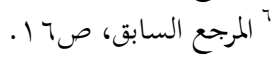




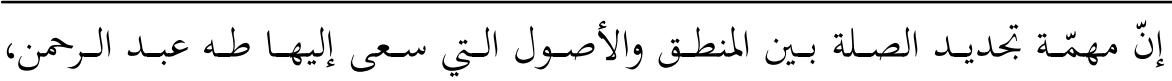

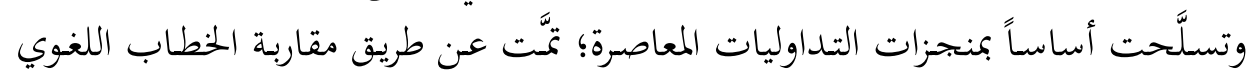

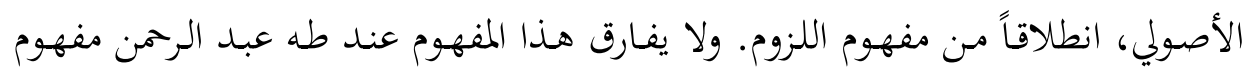

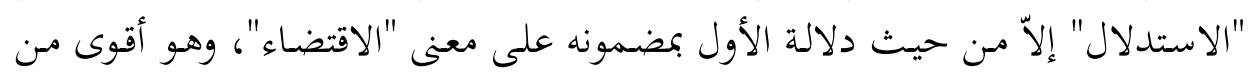

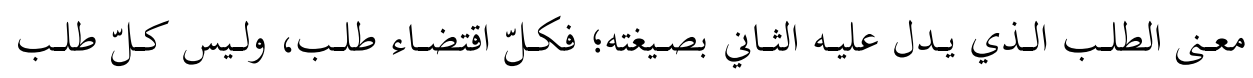

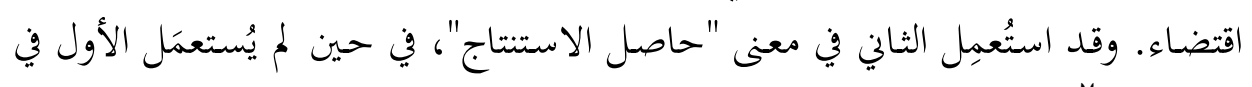
هذا المعنى.

أمّا مقاربة شكري المبخوت فتنطلق من "فرضية أساسية مفادها أن البلاغة العربية في

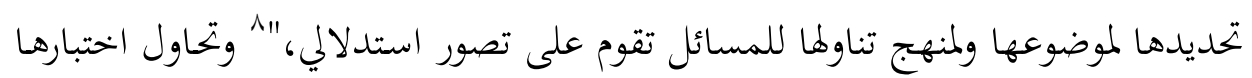

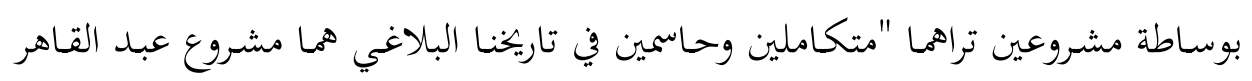

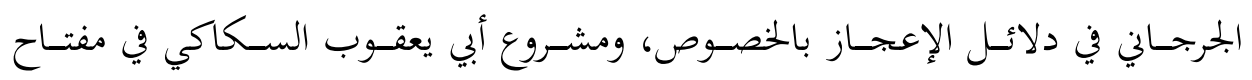
العلوم." الجرجن

\section{أولاً: الإنجاز التداولي: نظرية المناسبة}

ا ـ التداولية: التعريف، والمسار:

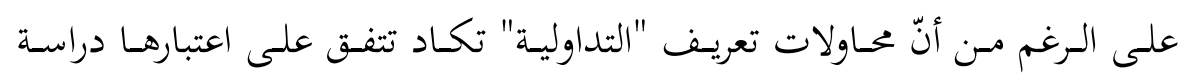

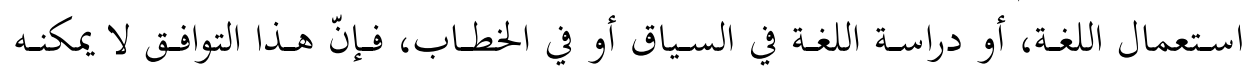

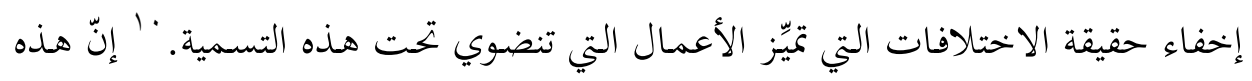

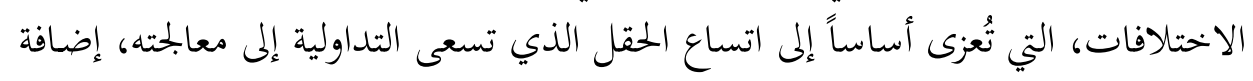

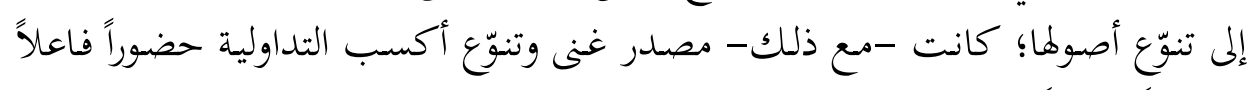
وانتشاراً متزايداً ضمن بحال الدراس كانت الدات اللغوية المعاصرة.

$$
\begin{aligned}
& \text { " المرجع السابق، صوحم. }
\end{aligned}
$$

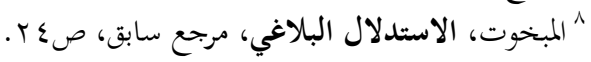

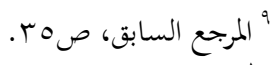

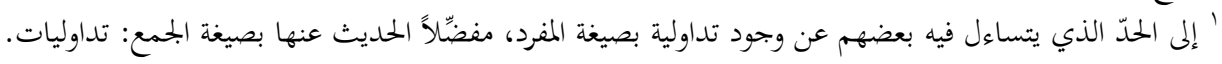

- بلانشيه، فيليب. التداولية من أوستين إلى غوفمان، ترجمة: صابر الحباشة، اللاذقية: دار الحوار للنشر والتوزيع، 
ويمكن التمييز ضمن مسار التداولية المعاصرة بين ثلاث مراحل، هي:

أ. مرحلة ما قبل النشأة الفعلية، أو وضعية المشروع غير المكتمل:

يُعزى ظهور هذا المصطلح إلى الفيلسوف الأمريكي شارلز مورس، الذي اقترح عام

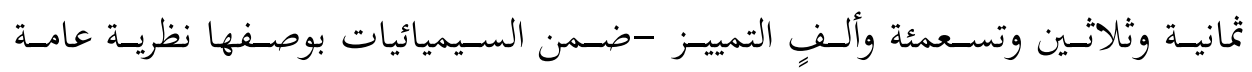
للعلامات- بين ثلاثة فروع، هي: التركيب، والدلالة، والتداولية. وإذا كان التركيب قد ولد اختص بلدراسة العلاقات بين العلامات، واهتمت الدلالة بعلاقة العلامات بما تدل عليه،

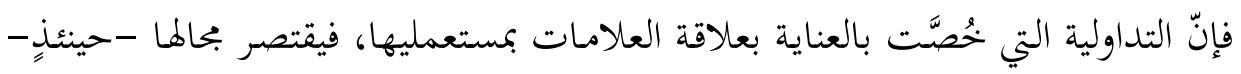
على دراسة ضمائر المتكلّم والمخاطَب، وظري المكان والزمان: الآن، وهنا، والتعابير التي بعاني

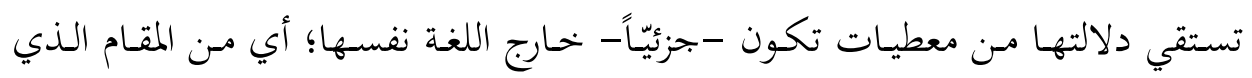
يجري فيه التواصل. ذلك -على الأقلّ- ما استقر في ذهن موريس. 'ل إنّ الخصـار التداوليـة في الألفـاظ الإشـارية (indexical)، وغيـاب الأعمـال الفعليـة

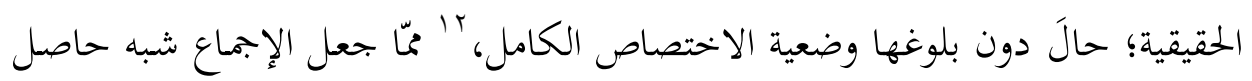

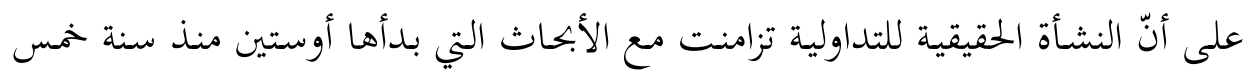

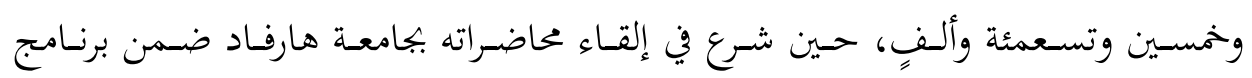
محاضرات وليام جيمس.

ب.مرحلة النشأة الفعلية، أو وضعية الاختصاص الكامل:

لم يكـن أوستين، وهـو يلقي محاضراته تلك، يسعى إلى "تأسيس اختصاص فرعي

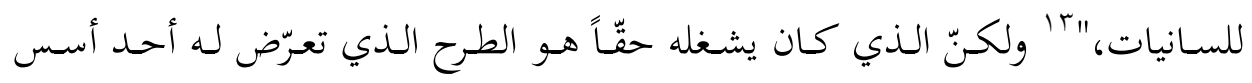

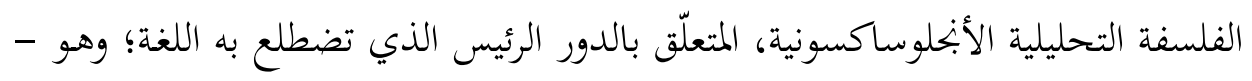

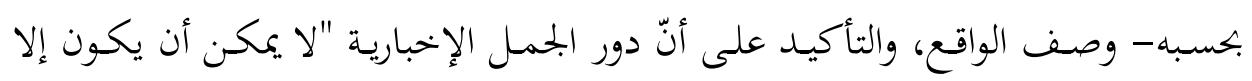

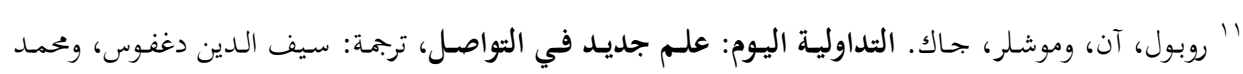

12 An Reboul (1995), La pragmatique à la conquête de nouveaux domaines:la référence, in l'information gramatical ,66,pp. 32 , 37.

$$
\text { r' روبول، التداولية اليوم: علم جديد في التواصل، مرجع سابق، صو r. }
$$


وصف حالة للأشياء، أو تأكيد حدث ما، والذي لا تستطيع هذه الجمل القيام به من

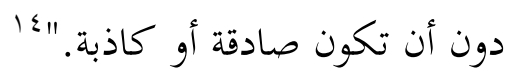

لقد انطلق أوستين لدفع ما كان يسميه بالمغالطة الوصفية؛ من أنّ بعض هذه الجمل

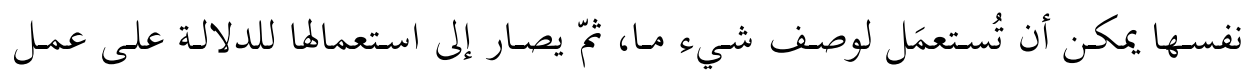

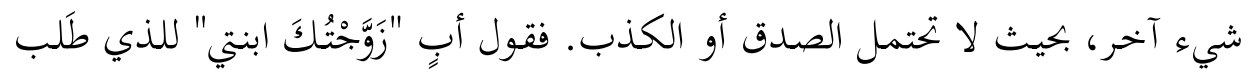

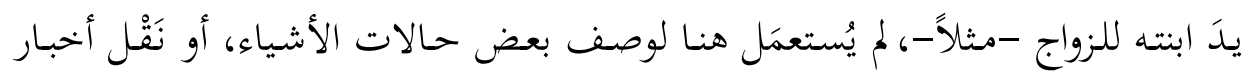

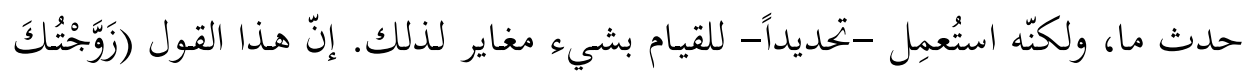

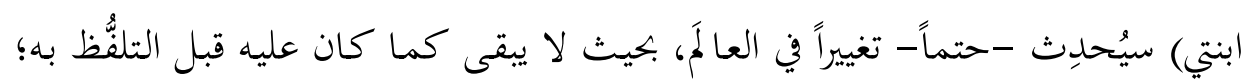

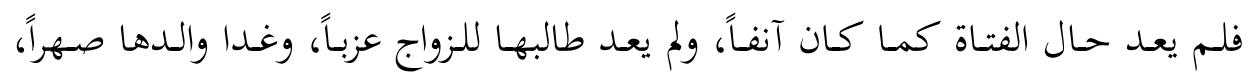
وانضمّت إلى هذا العالمَ عائلةُّ لم يكن لها وجود من قبلُ.

إنّ مـن أبـرز النتـائج المترتبّـة على هـذا النتـاش والحـوار، القـولَ بمفهوم "فهـل اللغـة"

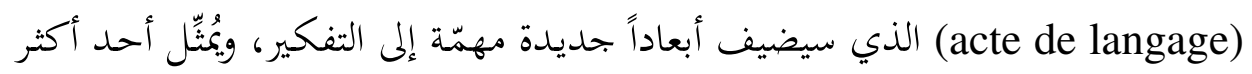

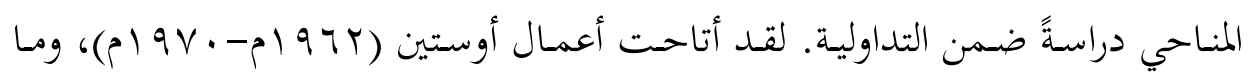

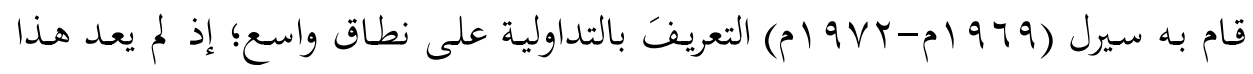
البحال قاصراً فقط على عدد محدود من الألفاظ الخاصّة (الألفاظ الإشارية)، التي يمكن النظر إليها على أفها حالات شاذة لا تحفل بأهمية كبرى في النسق اللساني؛ بل تعدّاها

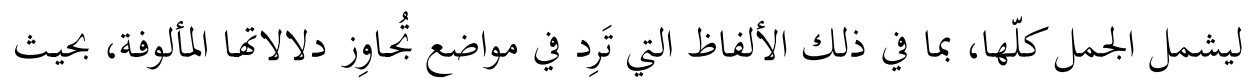
تضيف المعاني إليها أبعاداً أُخرى جديدة يُسهِم فيها القصد والسياق إسهاماً فاعلاً. لقـد مثَّلت هـذه المرحلة العصر الذهبي للتداوليـة؛ إذ أتاحـت لهـا الانتقـال مـن بحرّد فكرة محكوم عليها بالزوال والفناء إلى حقل متخصّص يحظى بدعم منقطع النظير.

14 J.L.Asustin, Quand dire,c'est faire,tr, Gille Lane ,1970,éditions du seuil,p ,37.

ترُّجم الكتاب إلى العربية، وقد حمل عنوان "نظرية أفعال الكلام: كيف ننجز الأشياء بالكلام؟". 


$$
\text { ج. مرحلة المسار الاستدلالي والمعري: }
$$

دشــت هـذه المرحلـة أعمـال الفيلسوف الأبحلوساكسـولي غـرايس، وبخاصـة نظريتـه

حول الدلالة غير الطبيعية ومنطقـه الحهواري، وتمثَّل إسهامه الأسـاس في إبراز أن معنى الملفـوظ لا يمكـن اختزالهه في محتواه اللسـاني (الـلالي)، ذلك أن المواضعة اللسـية لا لا تسمح وحدها باسترجاع مقصدية المتكلم في حرفيتها، الأمر الذي يستدعي سيرورات استدلالية تسمح بالتأويل الكامل للملفوظ.

إن قول غرايس بمفهوم الاستدلال آلية من آليات الفهم والتواصل ، وبمبدأ التعاون حاكماً وموجهاً لمما، إضافة إلى كونه أحسدَّ قطيعة بين اللسانيات والتداولية وبوّأ

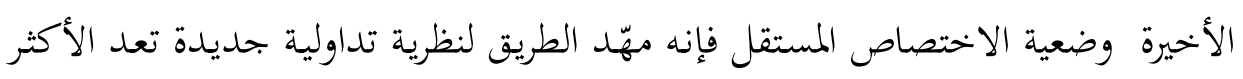

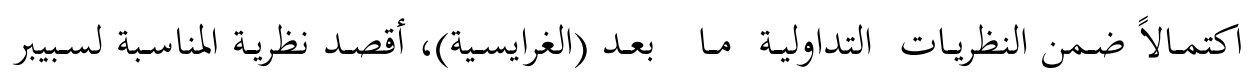
وولسون ذات الجذور الغرايسية والامتداد المعرفي.

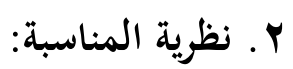

تنـدرج نظريـة "المناسبة" في سـياق تعـاون معـرفي أكـاديمي بـين الأنثروبولوجي (دان

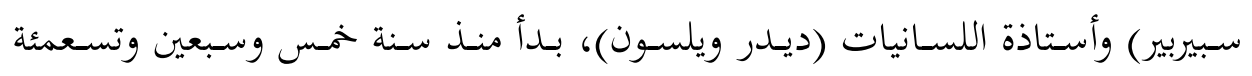

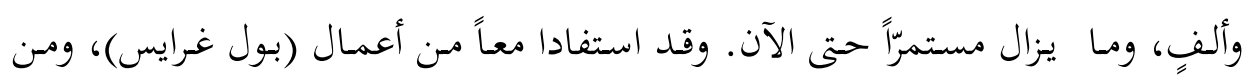
منجزات علم النفس المعرفي، ونشرا العديد من المقالات التي ناهزت قرابة اثنين وثلاثين

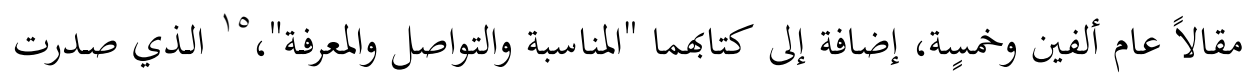

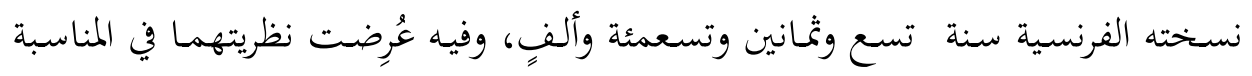
على نهو مكتمل. 17

${ }^{15}$ Dan Sperber et Deidere Wilson, La pertinence,communication et cognition,tr,Abel Grschenfeld et Dan Sperber,les éditions de minuit ;1989.

${ }^{16}$ Dan Sperber, Rapport d'activité 1965-2005,www.dan.sperber.com. 


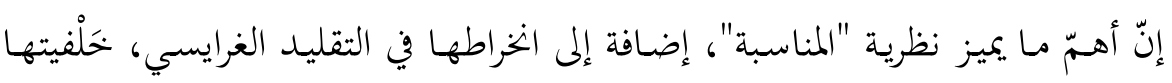

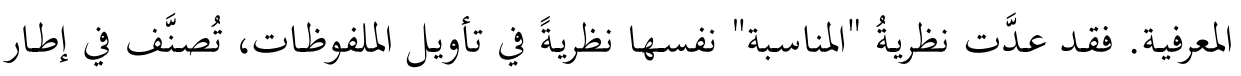

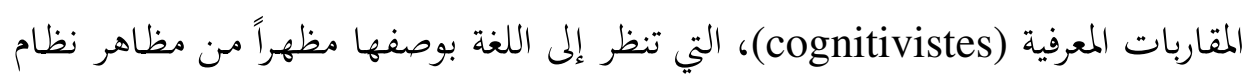

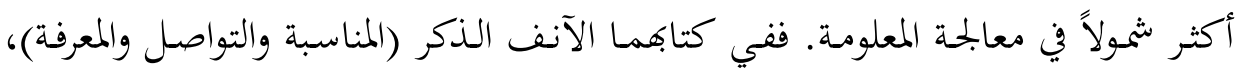

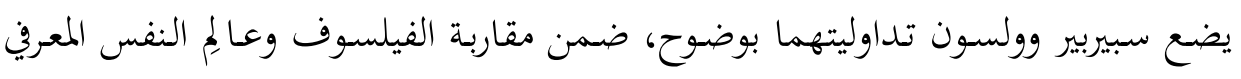

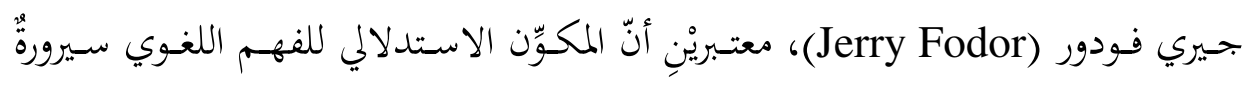

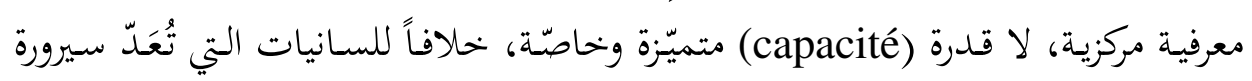

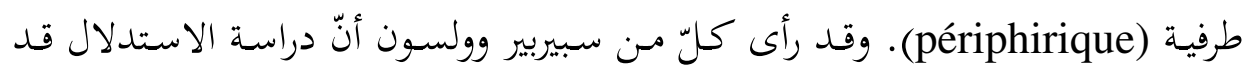

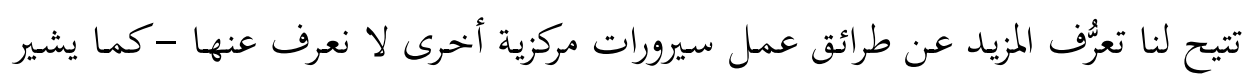
فودور - إلاّ القليل.

وبوجه عامّ، يقوم النموذج التداولي لنظرية "المناسبة" على مسلّمة، وينطلق من فرضية موَسَّسة على تمييز إجرائي، ويشتغل وَفق آلية معيّنة.

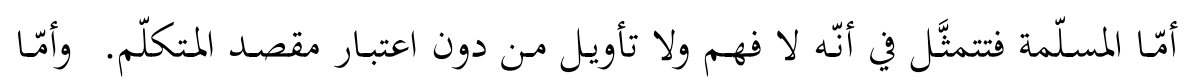

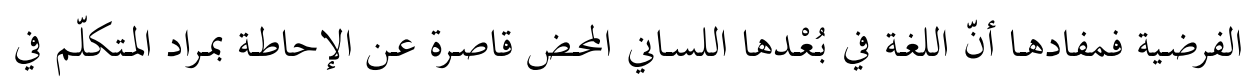

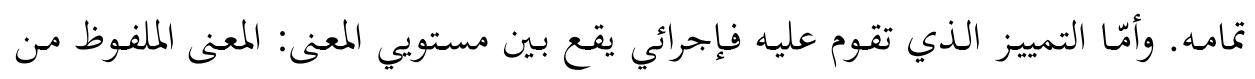

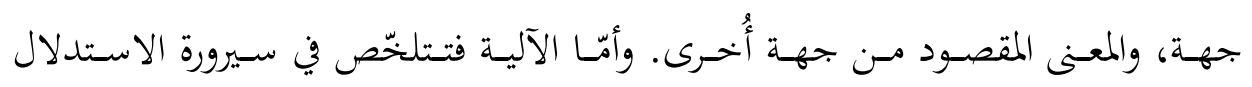
بمكوّنيها: الإشارة (ومن ضمنها العبارة اللسانية)، والسياق.

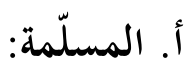

إنّ مـن أهمّم استحقاقات التداوليات المعاصرة إعـادة الاعتبار لمقصـد المتكلّم. فبإذا

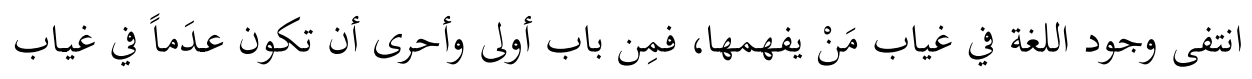

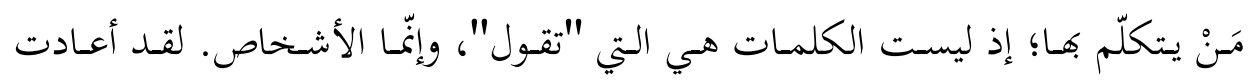

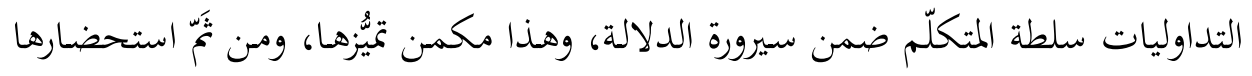
${ }^{17}$ Dan Sperber et Deidere Wilson, La pertinence,communication et cognition, P.104-106. 
لما غاب عند غيرها (دور السياق في إنتاج الكلام وتأويله). فقد انطلقت التداوليات -

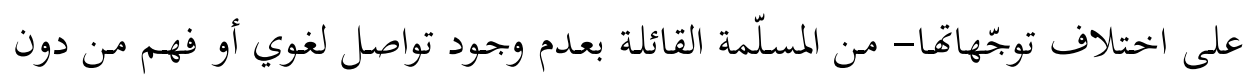
الاهتمـام بمقاصـد المتكلمّ، معتبرة -خحاصـة في توجّهها الغرايسي- أنّ الكائنسات البشرية

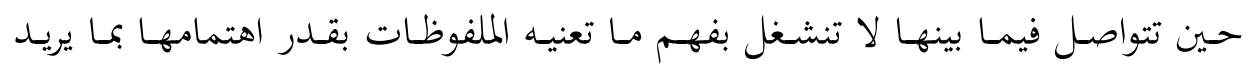

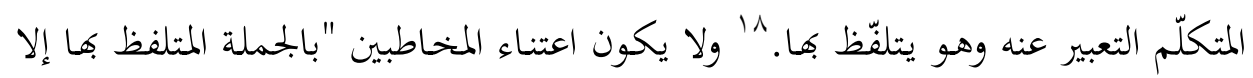

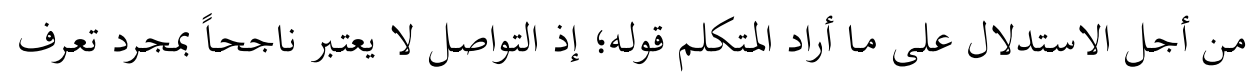
المخاطبين المعنى اللسائ للملفوظ بل يعتبر كذلك فتط حينما يستدلون على المعنى المراد للمتكلم. "19"

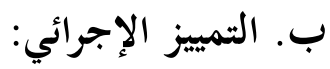

يسـتدل المخحاطَب على المعنى المـراد وفـق نظريـة "المناسـبة التداوليـة"، انطلاقـاً مـن

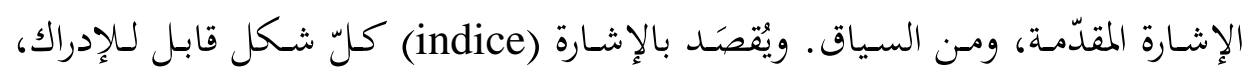

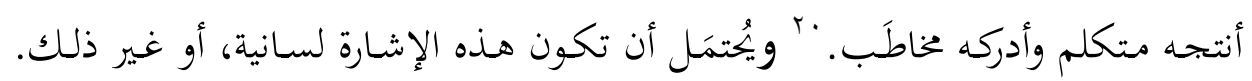

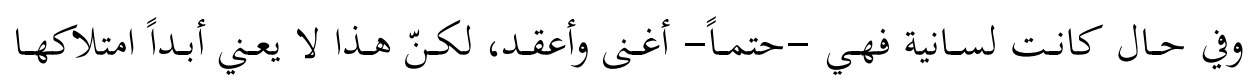
وحدها القدرة على مطابقة المعنى المراد من المتكلّم بوصفه الهدف الاستراتيجي في عملية الفهم والتأويل. لذا، ميَّز تداوليو المناسبة بوضوح بين وجهين من أوجه سيرورة التفاعل

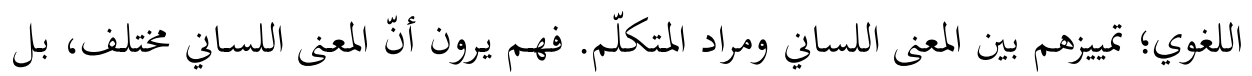

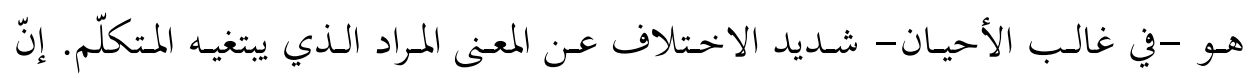

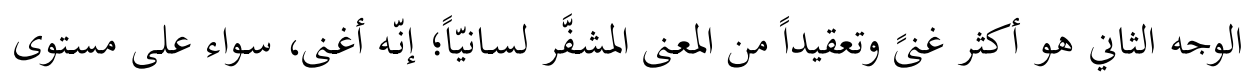

18 Dan Sperber et Gloria Origgi,(2005). Pourquoi parler, comment comprendre? In Jean-Marie Hombert, Ed. L'origine de l'homme, du langage et des langues. Fayard, Paris,pp. 236-253.

${ }^{19}$ Dan Sperber et Deidere Wilson, La pertinence,communication et cognition,P.42.

${ }^{20}$ Dan Sperber et Gloria Origgi,Pourquoi parler,comment comprendre,pp. 236-253. 


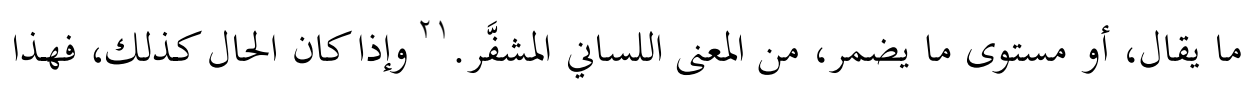

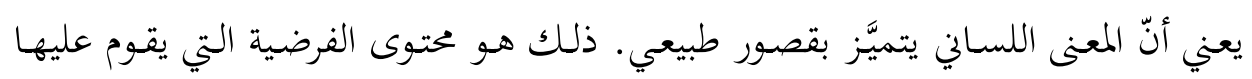
النموذج التداولي لنظرية "المناسبة" عند سبيربير وولسون.

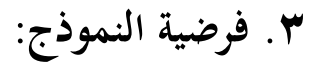

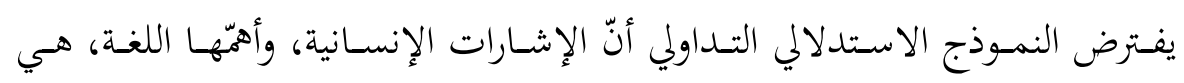

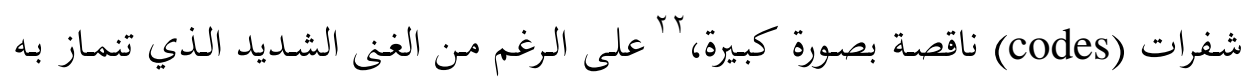

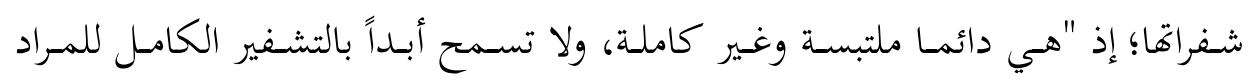

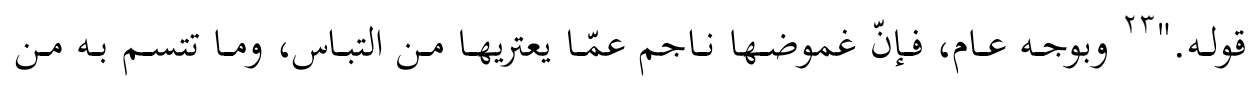

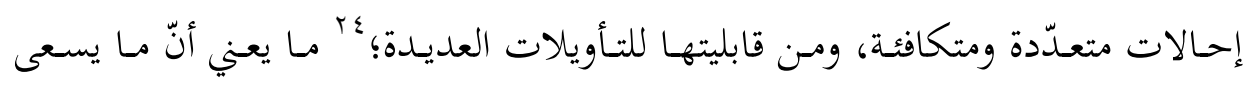

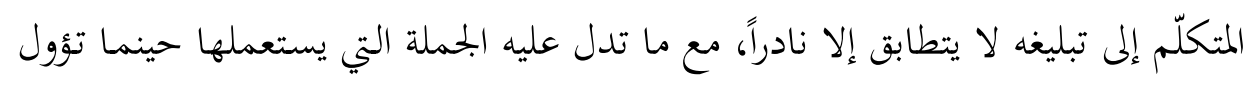

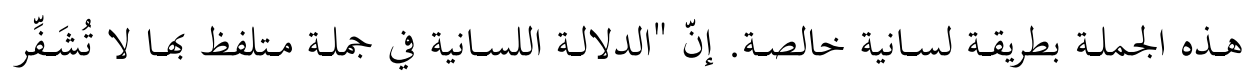

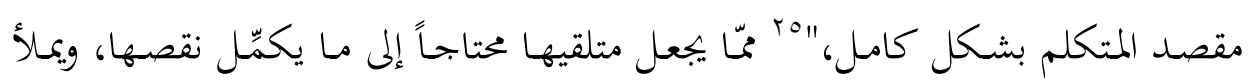

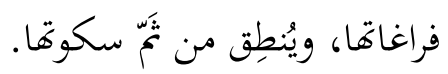

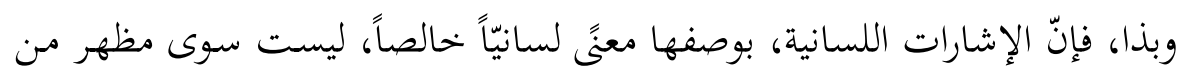

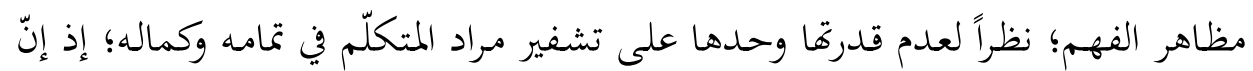

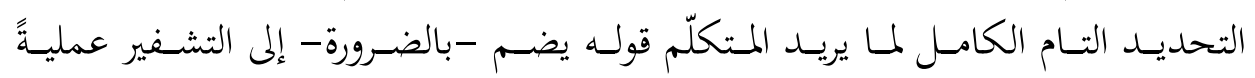

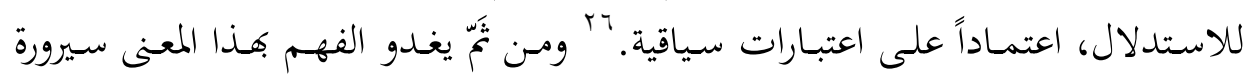

${ }^{21}$ Dan Sperber.(2000). La communication et le sens. Dans Yves Michaud (ed.) Qu'est-ce que l'humain? Université de tous les savoirs, volume 2. Paris: Odile Jacob ,pp. 119-128.

${ }^{22}$ Dan Sperber et Gloria Origgi,Pourquoi parler,comment comprendre,pp. 236-253.

${ }^{23}$ Dan Sperber, La communication et le sens,pp. 119-128.

${ }^{24}$ Dan Sperber et Deidere Wilson, La pertinence,communication et cognition,P57.

${ }^{25}$ Ibid, P48.

${ }^{26}$ Dan Sperber, Rapport d'activité 1965-2005,www.dan.sperber.com. 


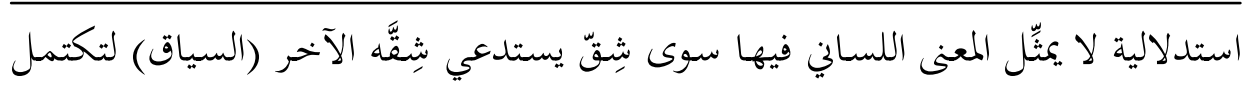

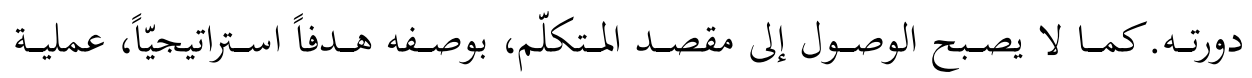

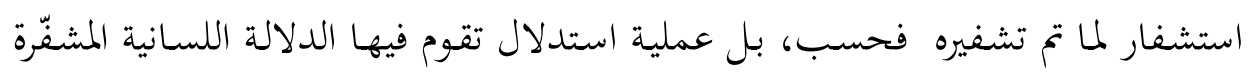

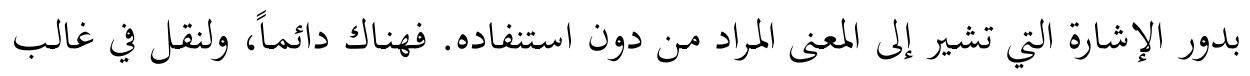

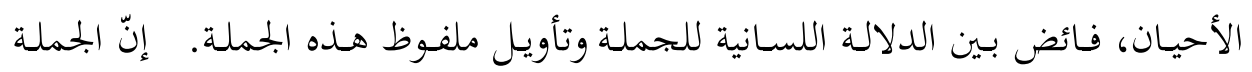

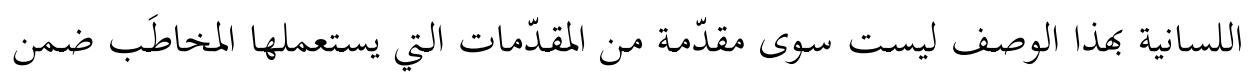

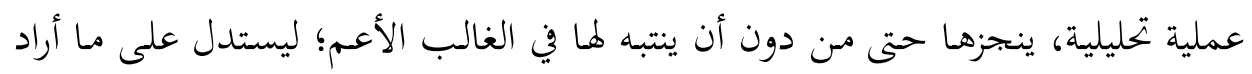

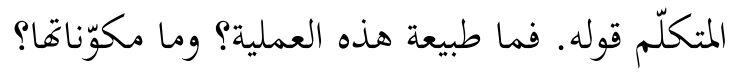

\section{ع ـ آلية النموذج (الاستدلال):}

يُعَدِّ الاستدلال مـن أهمّ آليات العقل، و بتحلّ من أبرز تجحلّياته، به يتفاعل الإنسان

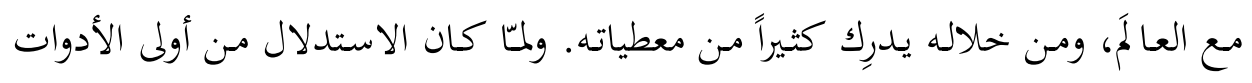

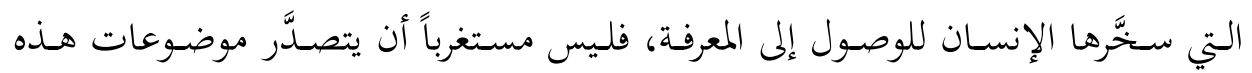

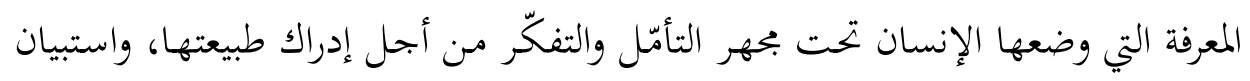
طرائق اشتغالها، وتعرّف مدى ملاءمتها، وتحديد مستويات يقينيتها.

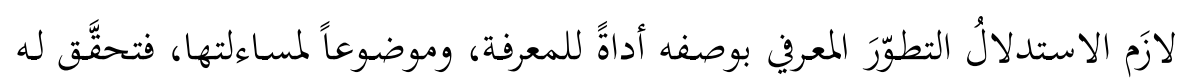

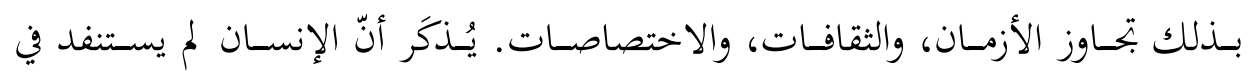

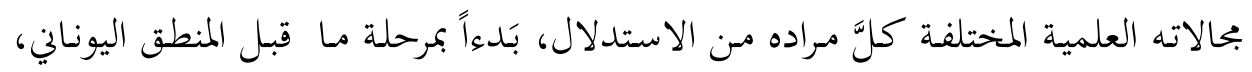

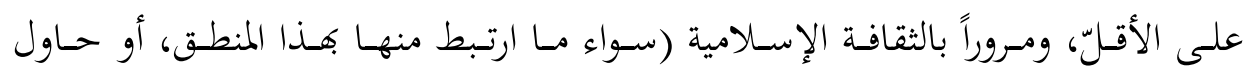

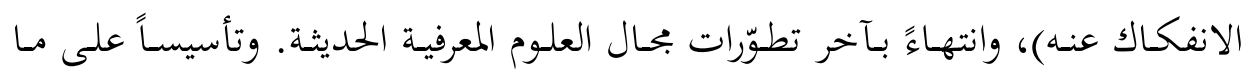

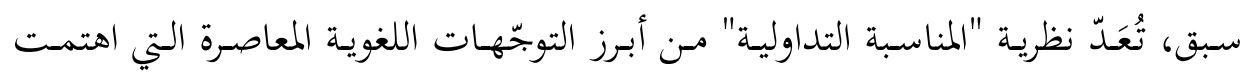

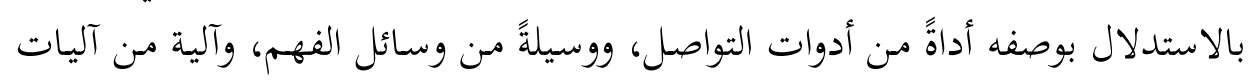
التأويل والقراءة.

\section{أ. الاستدلال اللغوي: المفهوم، والطبيعة:}

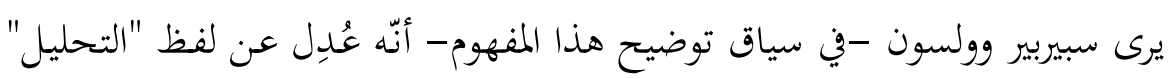
(analyse) 


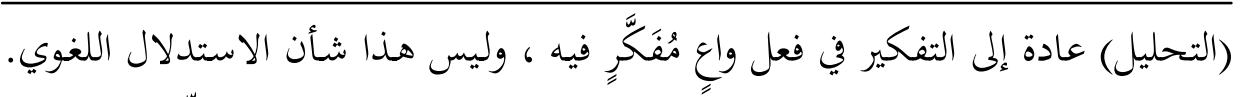

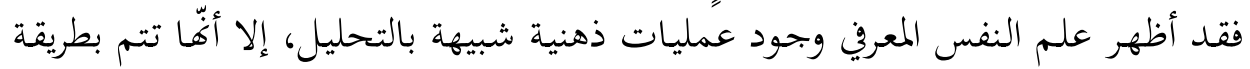

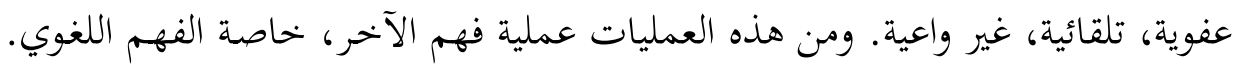

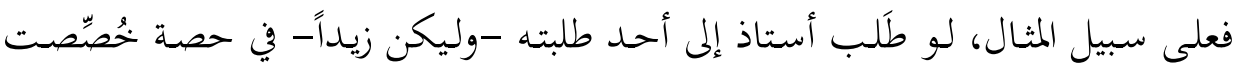

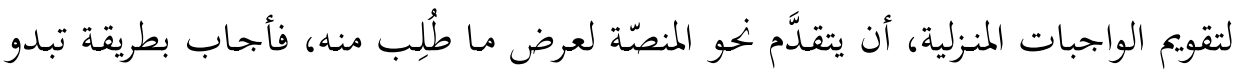

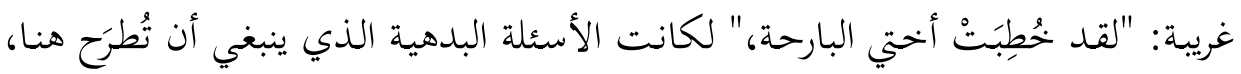

$$
\begin{aligned}
& \text { - ما علاقة هذا الجواب بطلب الأستاذ؟ }
\end{aligned}
$$

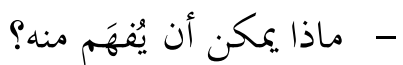

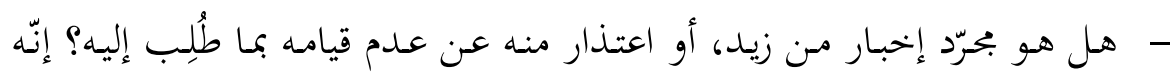

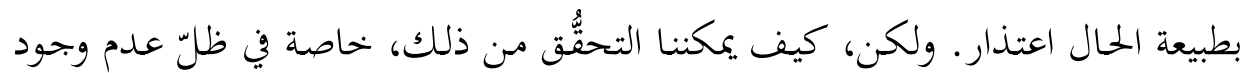

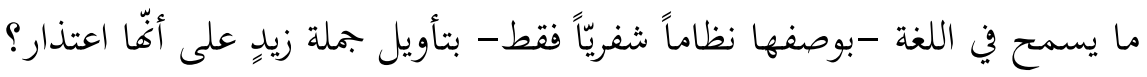
لمعرفة ذلك، ينبغي التفكير في المعطيات الآتية:

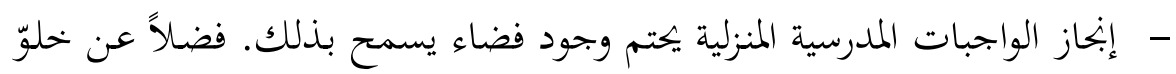
ذهن الطالب من أيّ انشغال قاهر. - - خطبة الأخت تتطلّب عمل ترتيبات عدّة تحول دون أداء الطالب واجباتِه. - مجوب مشاركة الأخ أختَه الفرحة.

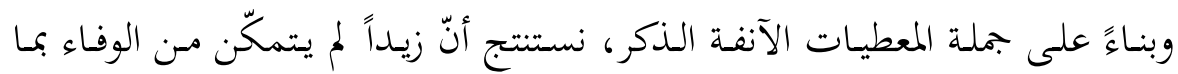

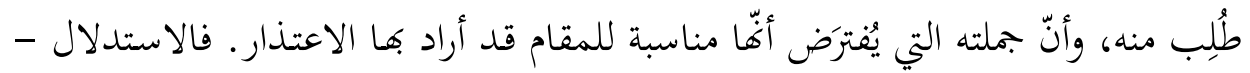

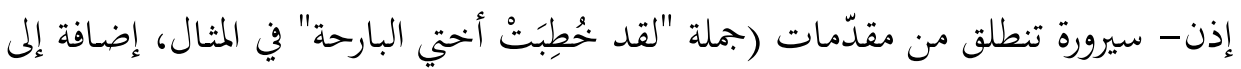

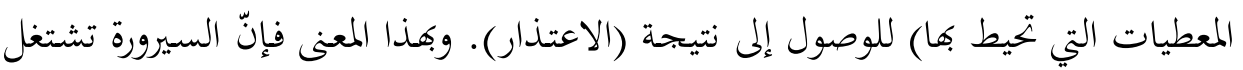
بوصفها تحليلاً، غير أفّا تجري بطريقة لتوصول تلقائية وغير واعية.

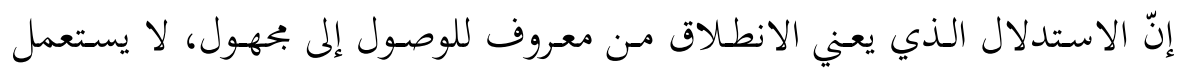

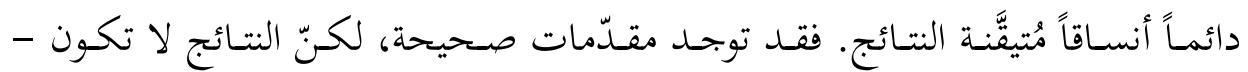

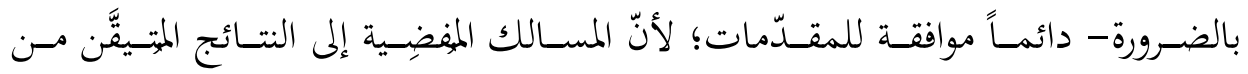

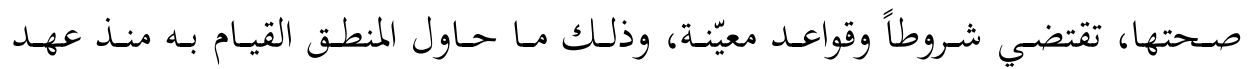


أرسطو، في مـا سمّيّي بالقياس البرهاني؛ فكلّمـا كانت المقتدّمات صحيحة كانت النتائج

إنّ المقـدمّات في سـيرورة الاستـلال اللغوي ليسـت سـوى فرضـيات ينطلق منهـا

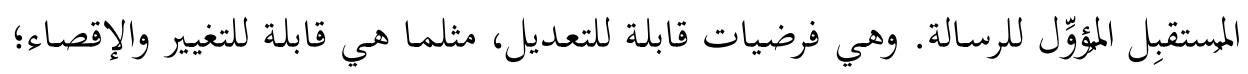

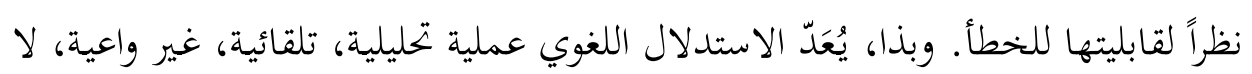

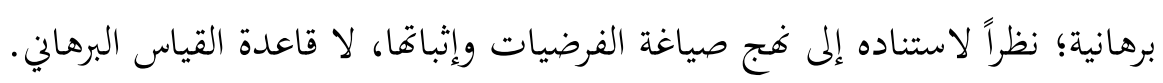

\section{ب. مكوّنا الاستدلال اللغوي (الإشارة والسياق):}

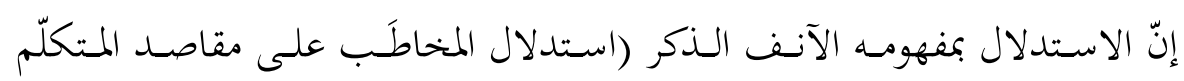

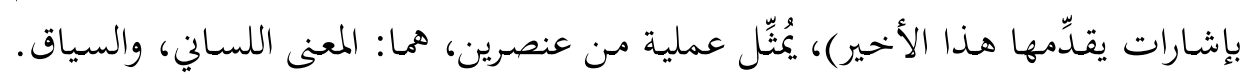

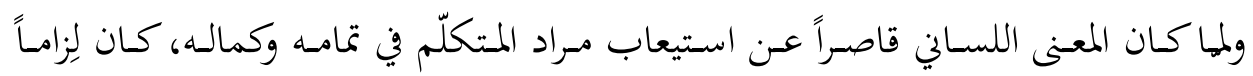

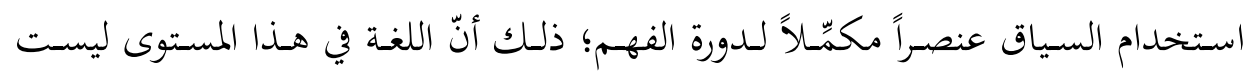

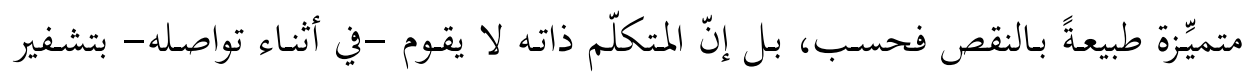

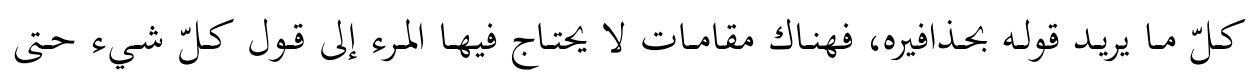

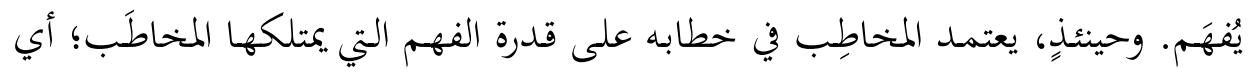

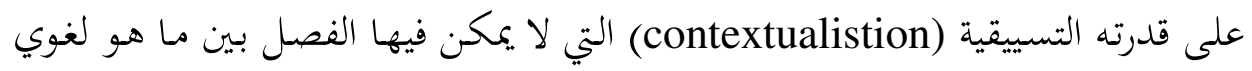
محض، وما هو عمليات ذهنية استدلالية تستثمر معطيات العالمَ الخارجي ومعارفه.

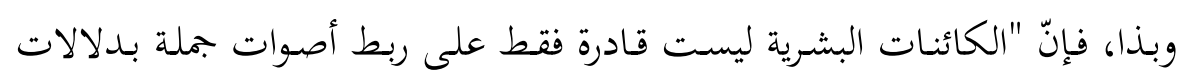

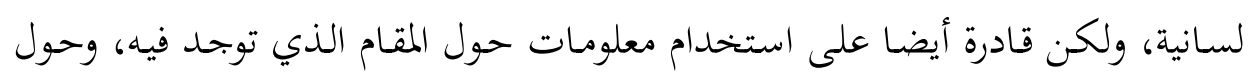

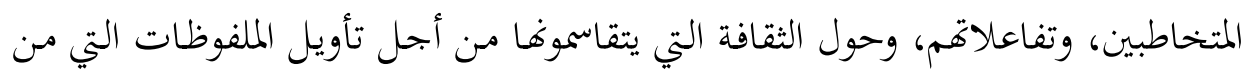
دون ذلك تبقى كأشتات معنى من دون محتوى محدد."

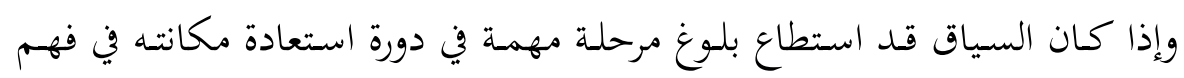

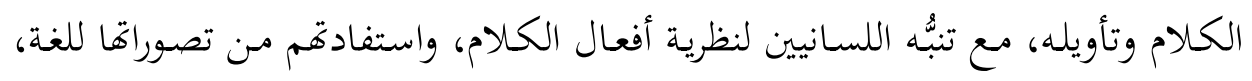

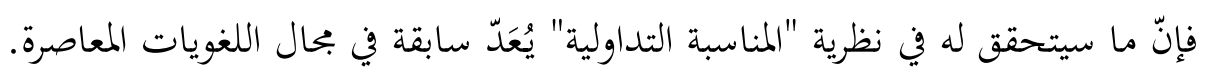

${ }^{27}$ Dan Sperber et Gloria Origgi,Pourquoi parler,comment comprendre, pp.236-253. 


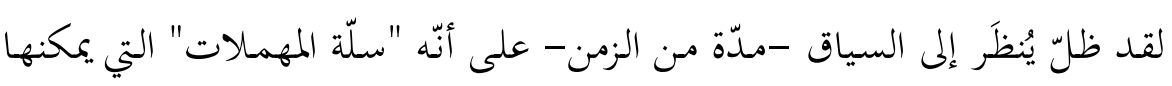

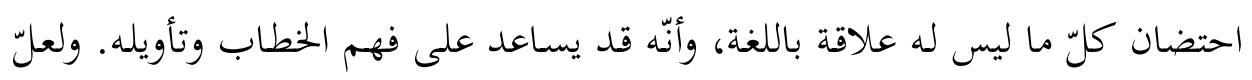

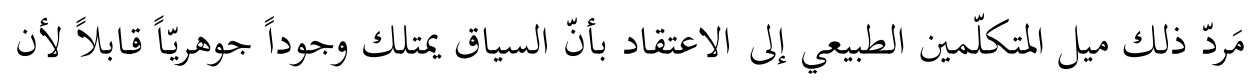

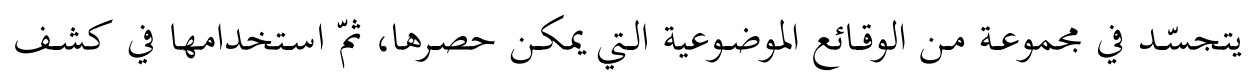

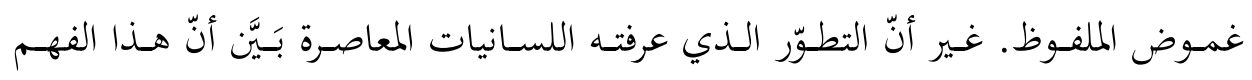

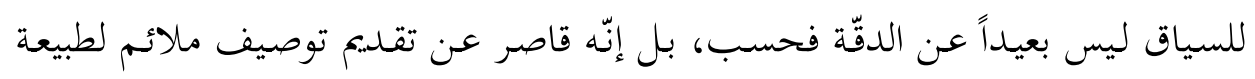

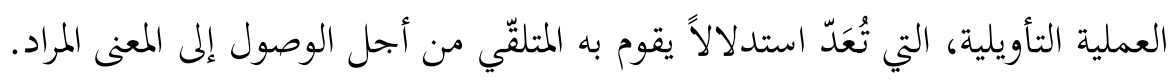

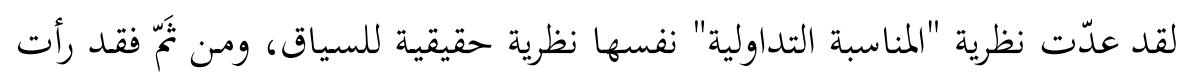

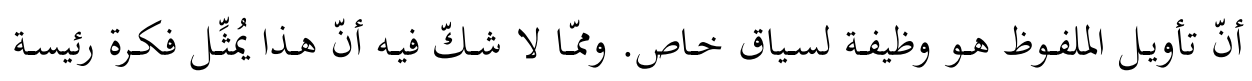

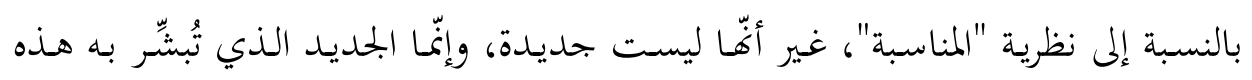

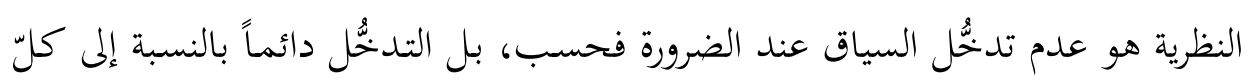

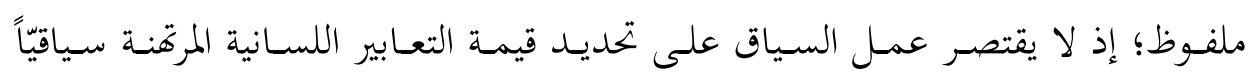

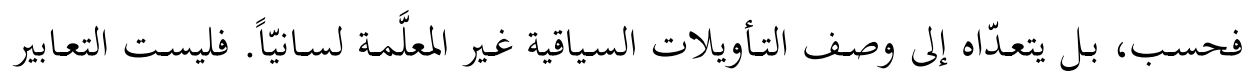

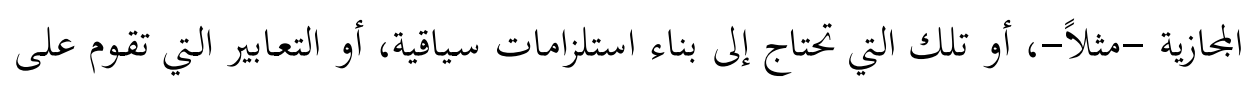

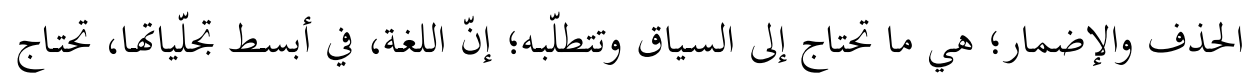

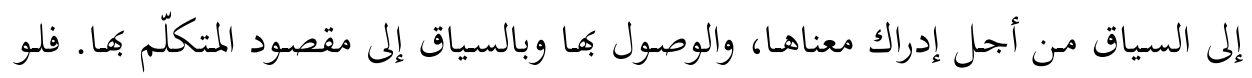

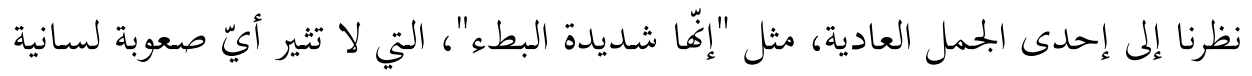

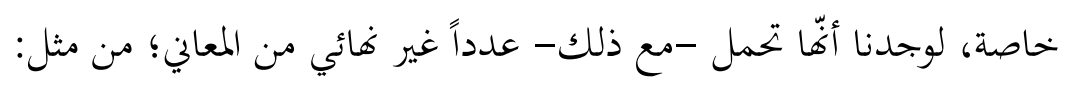

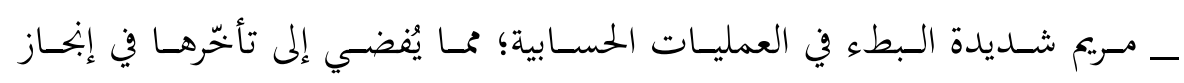
فروضها. ــ التفاعلات أشدّ بطئًاً متّا كان متوقّاً لما. ــ معدلات البطالة تنخفض ببطء شديد، مثّا يعوق تمقيق الإنحازات الاجتماعية 


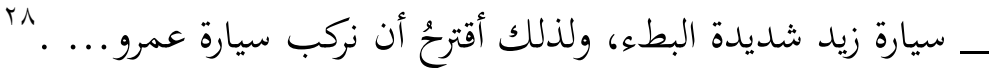

وعليه، ينبغي للمخاطَب -مـن دون شكّّ- امتلاك معلومات سياقية؛ ليتمكَّن من

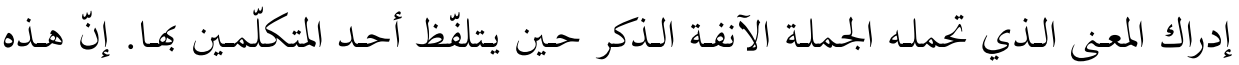

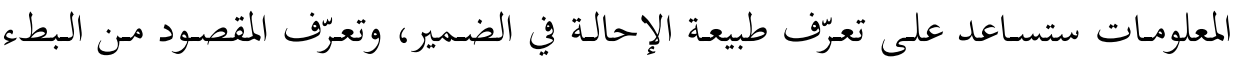
المشار إليه في هذه الجملة (بطء في الحركة، بطء في التفكير، بطء في...). كما ستساعد إند هذه المعارف السياقية على تحديد طبيعة الملفوظ من حيث الحَرْفية، أو الانزياح عنها.

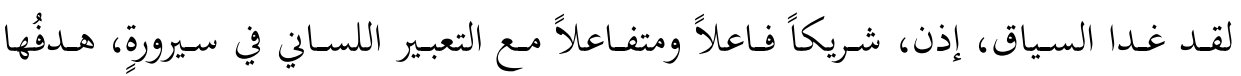
النهائي الوصول إلى مقصد المتكلّم. فما المقصود من السياق في نظرية "المناسبة"؟ يُعرِّف سبيربير وولسون السياق بأنّه "بحموع المقدمات المستعملة لتأويل الملفوظ." ·r

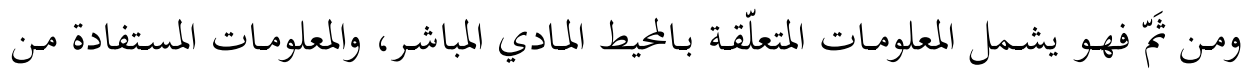

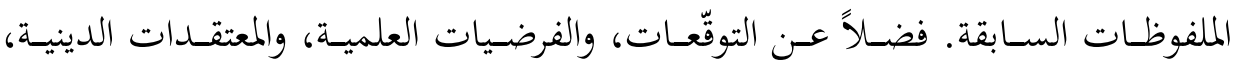
والذكريات، والأحكام الثقافية المسبقة، والافتراضات الخاصّة بحالة المتكلمّ الذهنية. وعليه،

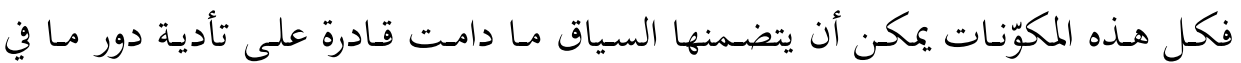
التأويل. 'ب إنّ السياق باختصار هو تلك المحموعة من "الافتراضات التي يملكها المخاطب

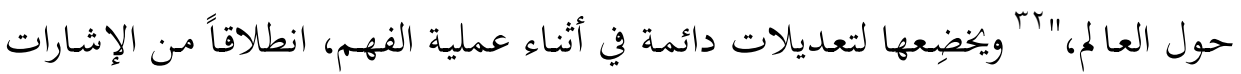
اللغوية (أو حتى غير اللغوية) التي يتلقّاها. كلّ ذلك يتم في بوتقةٍ تتفاعل فيها المعلومات اللسانية بالمعلومات غير اللسانية، بحيث يصبح اللساني ذاته معطى سياقيّاً، ليتحوَّل الكلّ ئل ${ }^{28}$ Dan Sperber et Gloria Origgi, (2005). «Qu'est-ce que la pragmatique peut apporter à l'étude de l'évolution du langage? »In: Jean-Marie Hombert (Ed). L'origine de l'homme du langage et des langues,Paris: Fayard, pp. 236-253.

${ }^{29}$ Ibid, pp. 236-253.

${ }^{30}$ Dan Sperber et Deidere Wilson, La pertinence,communication et cognition,P.31.

${ }^{31}$ Ibid,P.31.

${ }^{32}$ Dan Sperber et Deidere Wilson, La pertinence,communication et cognition,tr,P.31. 


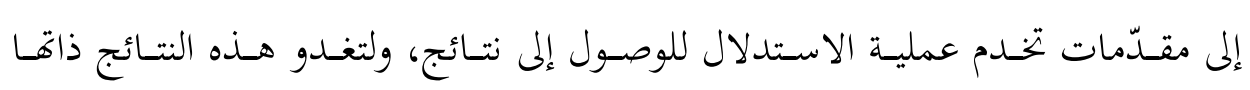
مقدّمات يمكن فَهْمْ الملفوظات اللاحقة استناداً إليها.

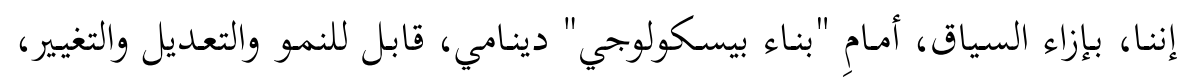

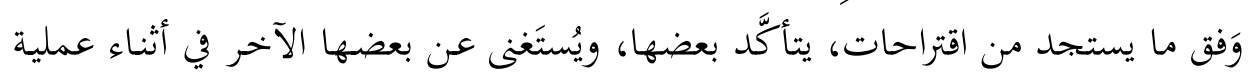

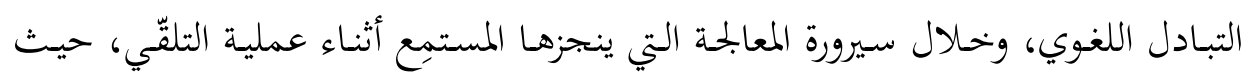

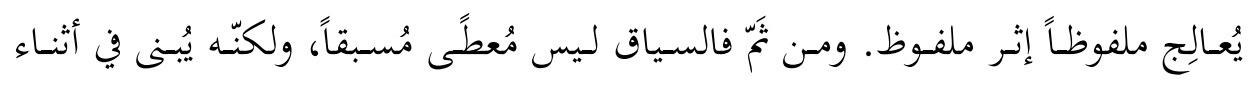

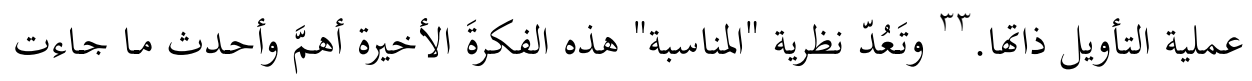
به بخصوص السياق.

وفي حال كان السياق، بوصفه أحدَ مكوِّين العملية الاستدلالية، عنصراً ديناميّاً غير

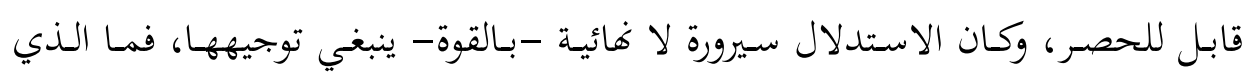

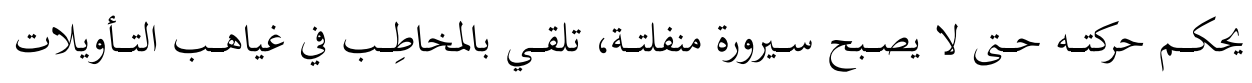

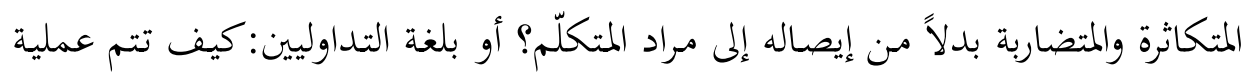
الاستدلال هذه؟ وما الذي يوجّهها؟

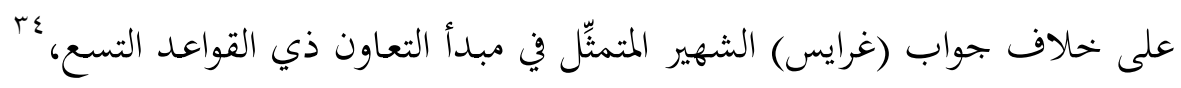

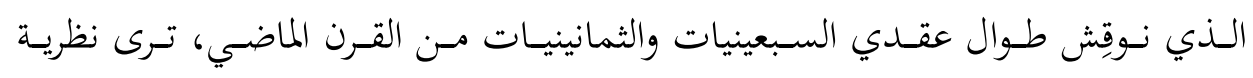

${ }^{33}$ Dan Sperber, Rapport d'activité 1965-200.

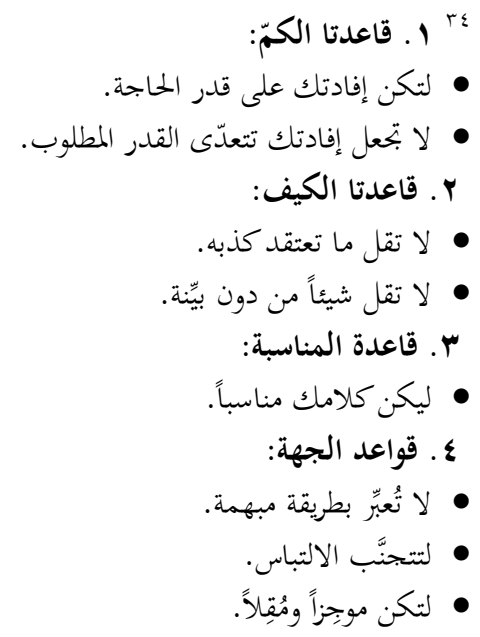


"المناسبة" -بوصفها تطويراً لما قـام بـه غـرايس - أنّ هـذه السيرورة هي موجَّهـة بوسـاطة

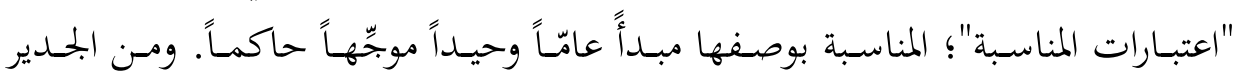

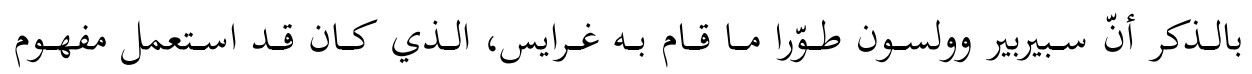
"المناسبة" قبل ذلك في إحدى مسلّماته التخاطبية (ليكن كلامك مناسباً). قاعدة المناسبة الغرايسية، إذن، هي كلّ مـا احتفظ بـه سبيربير وولسون من قواعد

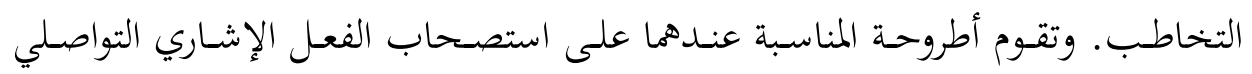

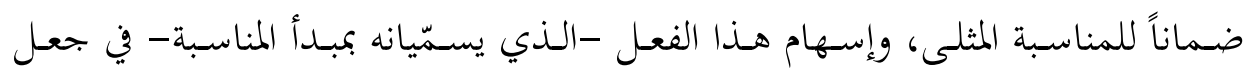
المقصد الذي تتضمّنه الإشارة جليّاً.

وبوجــه عـام، يقـوم مبــأ "المناسـبة" على مفهـوم "المناسـبة" الـذي يعـني أنّ الفعـل التواصلي يكون مناسباً إذا أنتج آثاراً معرفية كثيرة بأقلّ جهد ذهني. ويمكن تلخيص هذوم هذه الآثار المعرفية في ما يأتي: تحصيل معتقدات جديدة، وإقصاء معتقدات سابقة، وإضعاف إفاف

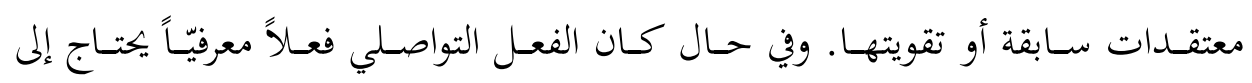

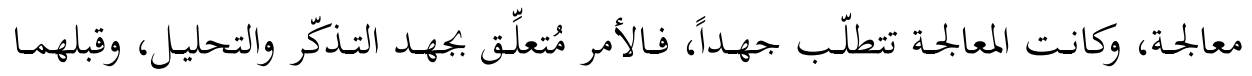

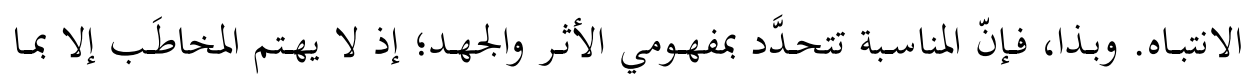

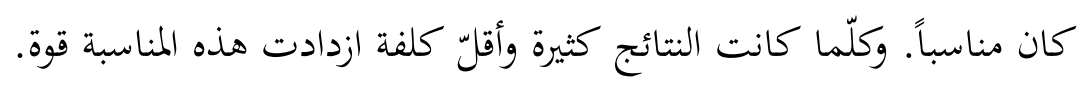
وعلى الرغم من الحداثة الزمنية لمذا الإنجاز، وما تبعه من تميّزٍ في سياقه المعرفي المتصل

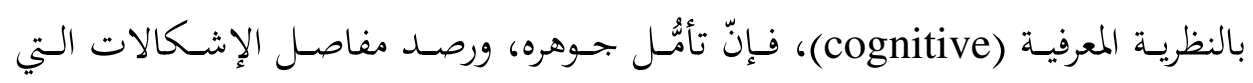

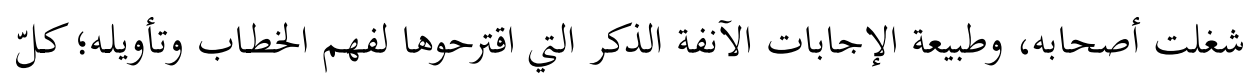

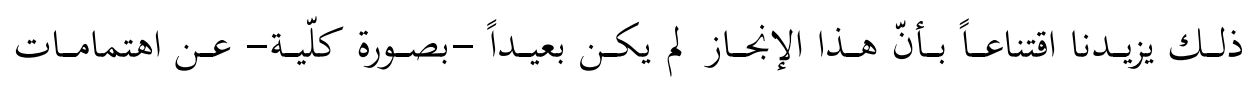

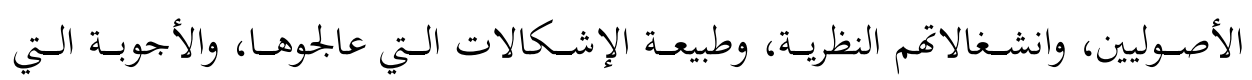

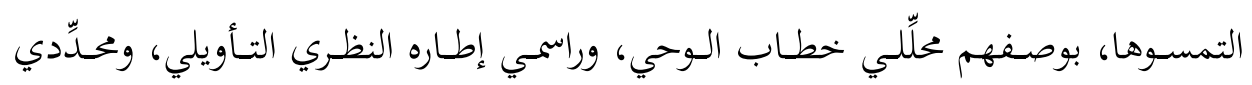
مساطره الإجرائية.

${ }^{35}$ Dan Sperber et Deidere Wilson, La pertinence,communication et cognition,tr,P.82. 


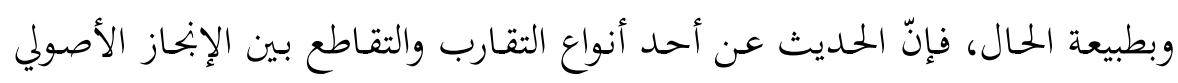

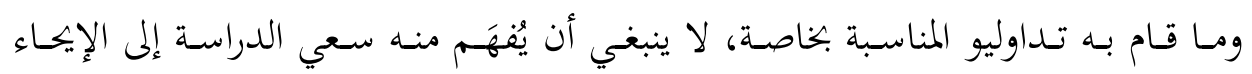

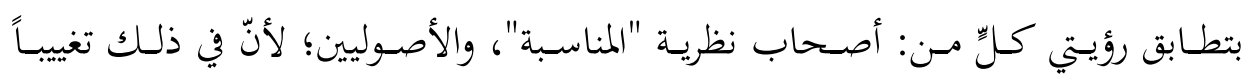

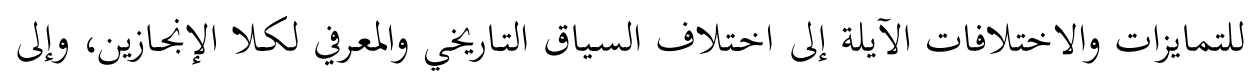

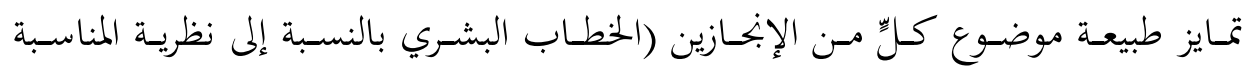
التداولية، خاصة الشفوي منه، وخطاب الوحي بالنسبة إلى الأصوليين). غير أنّ القول

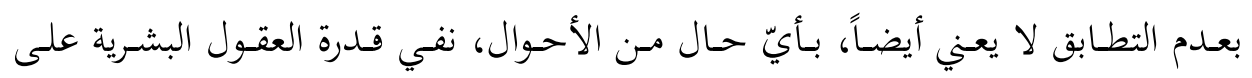

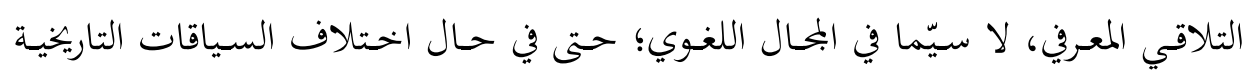

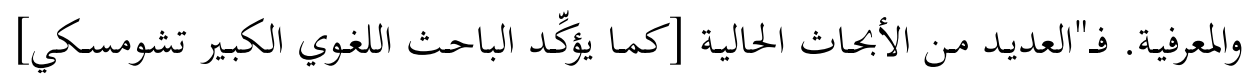

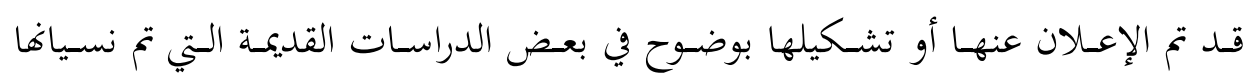

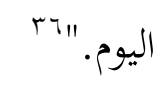
إنّ هـذا المعطى الذي يُنبِّه عليه تشومسكي هـو نفسه الذي يشير إليه الفيلسوف

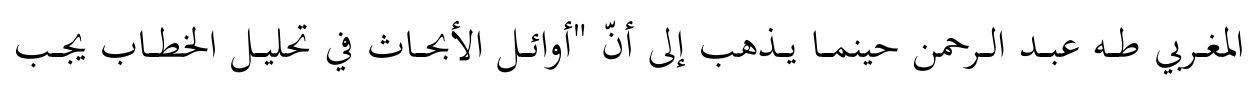
طلبها في ما أفاض فيه الأصوليون من مقدمات في تحديد الدلالات وتصنيفها وما أفردوه

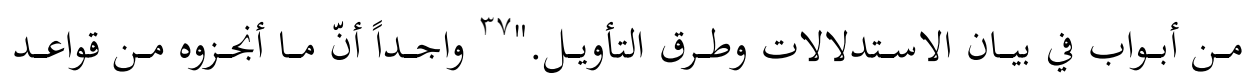
خطابية، لا سيّما في باب الاقتضاء والمفهوم "تفاجئنا بمضاهاتما لما يعرض اليوم في سياق

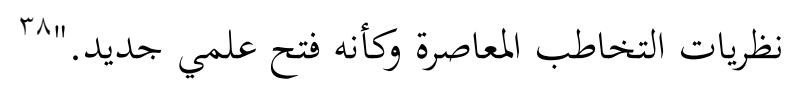
وتأسيساً على ما سبق، وبعيداً عن دعوى التطابق، وعن كلّ ما من شأنه أن يبخس

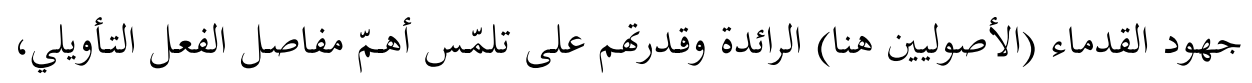

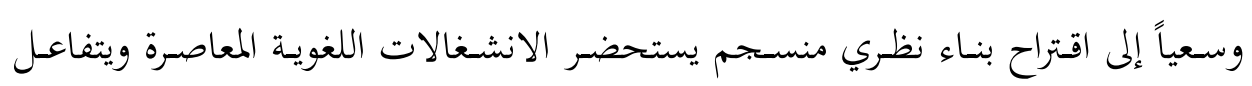
معها؛ نسوق في ما يأتي الإبحاز الأصولي.

${ }^{36}$ Chomsky, N, La linguistique cartesienne,tra, N.Delanè et D. Serber, Seuil, Paris, p.112.

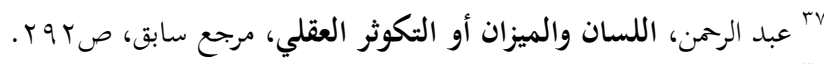

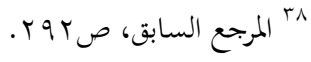


ثانياً: الإنجاز الأصولي

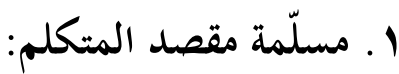

إحدى السمات الجوهرية للخطاب الأصولي هي أنّه خطاب مقاصدي؛ حتى إنّ إنّا

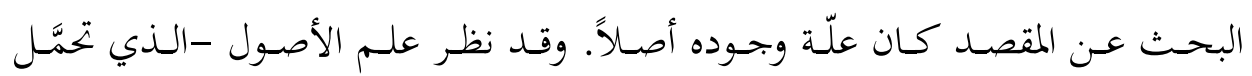

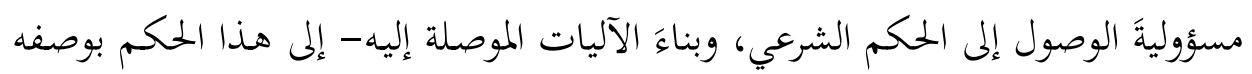

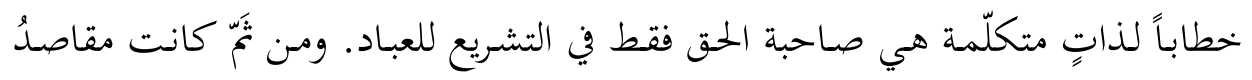

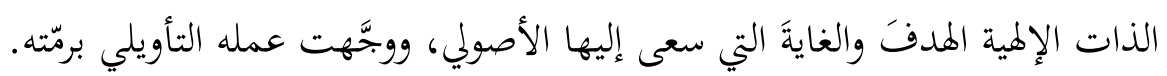
وعليه، فليس غريباً ملاحظة أنّ تعامل الأصوليين مع الفعل اللغوي من حيث هو إنو

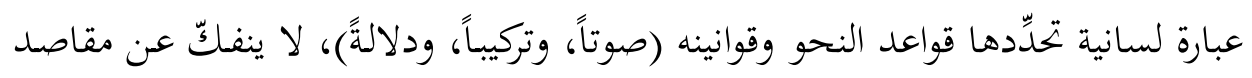

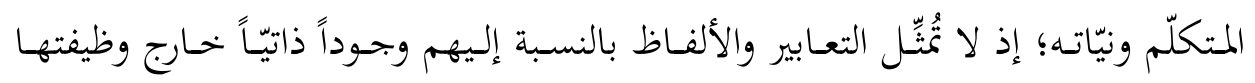

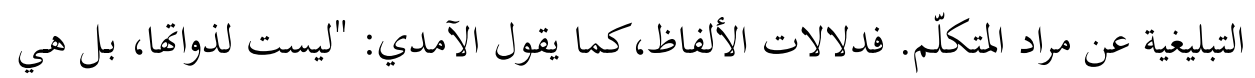

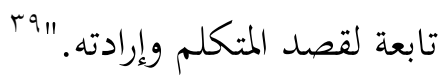

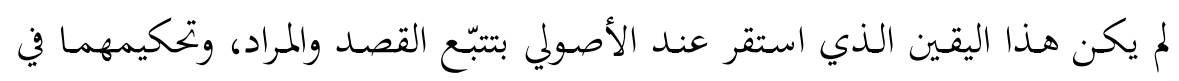

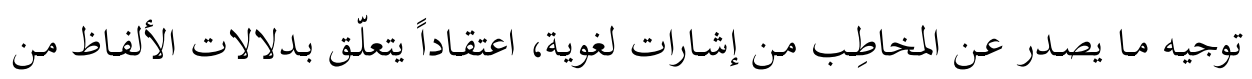

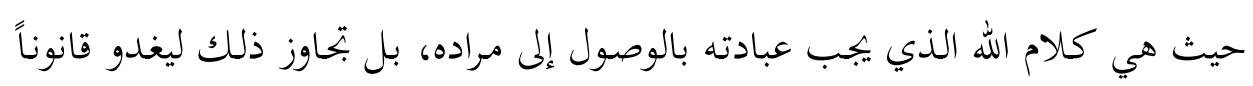

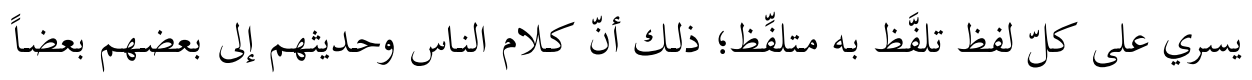

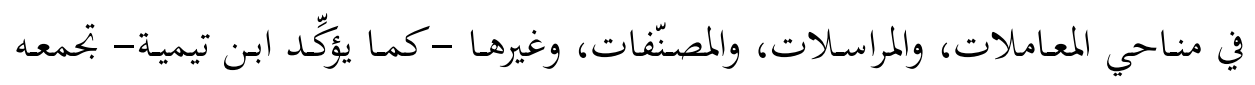
كلّه دلالةُ اللفظ على قصد المتكلم ومراده. . ؛

إنّ الأمر يتعلّق -أساساً- بوعي الأصوليين العميق بإحدى مسلّمات التواصل التي

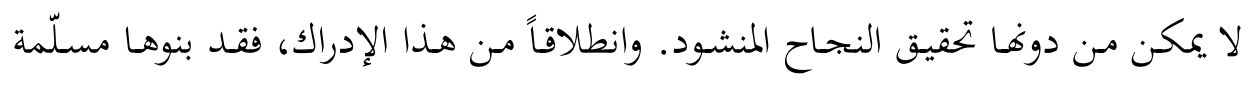

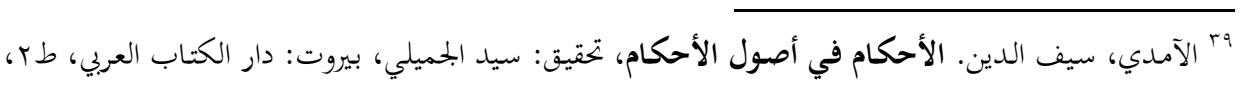

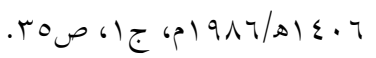
•" ابن تيمية، أمدا أبو العباس. الاستقامة، تحقيق: عمد رشاد سالم، المدينة المنورة: جامعة الإمام عمد بن سعود،

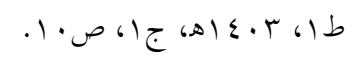




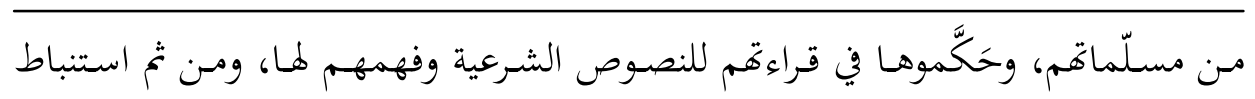

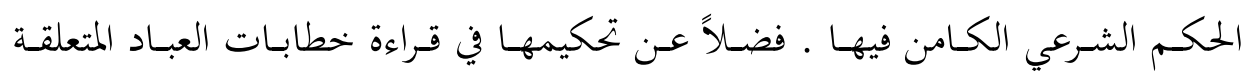

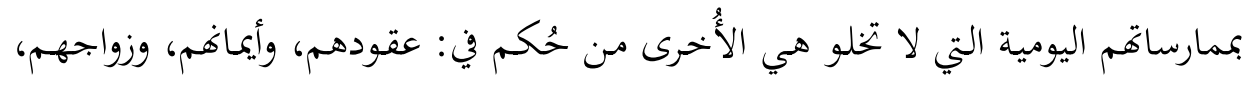

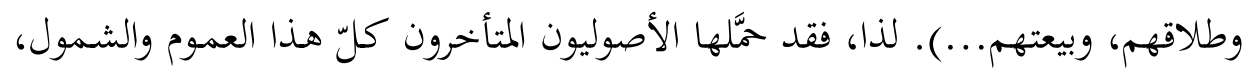

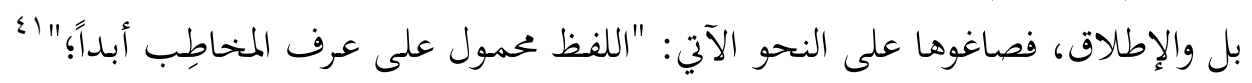

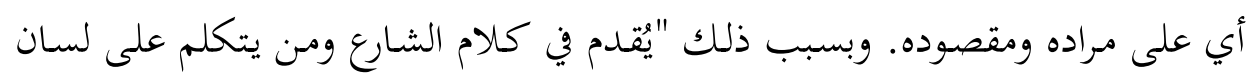

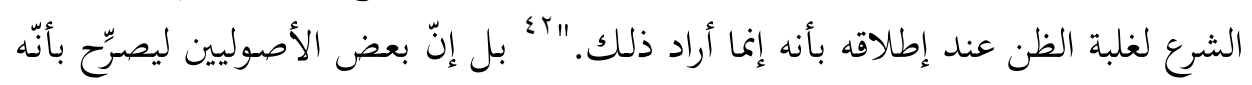

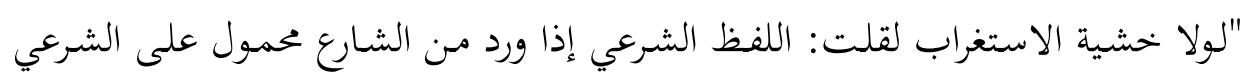
قبل اللغوي اتفاقاً؛" آع أي محمول على قصده ومراده.

\section{ץ. احتمالية الفعل اللغوي ودور السياق:}

على الرغم من تسليم الأصوليين بمسلّمة المقاصد وإعمالها في النظر إلى الخطاب، إلا

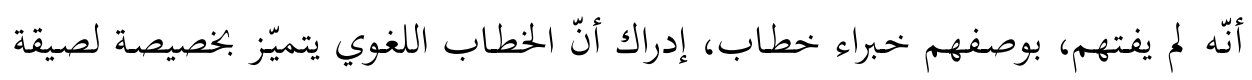

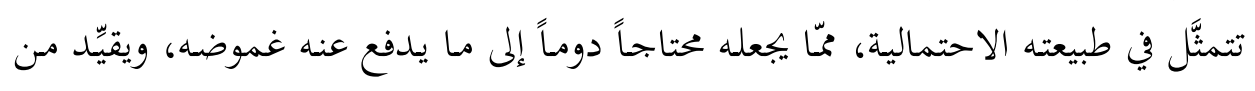
إمكانات إحالاته، ويضيّق من مساحة تعدّده الدلالي.

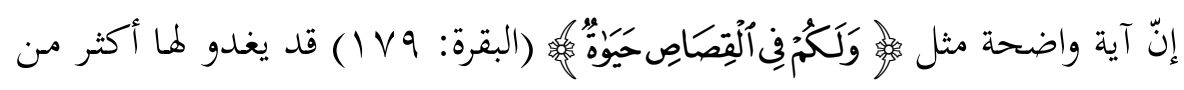
إمكان تأويلي، كما أوضح ذلك الأصولي جمال الدين الإسنوي. وقد أورد لها في كتابه ثلاثة تحقّقات من هذه الإمكانات:

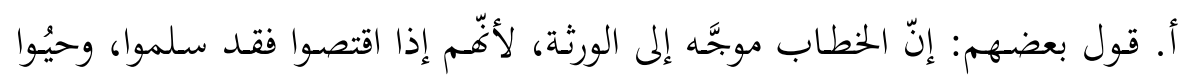
بدفع شرّ هذا القاتل الذي صار عدّواً لهم بالقتل.

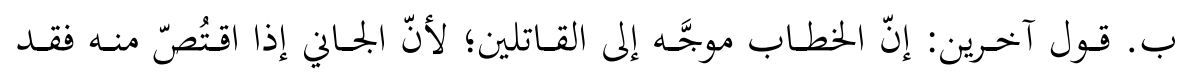

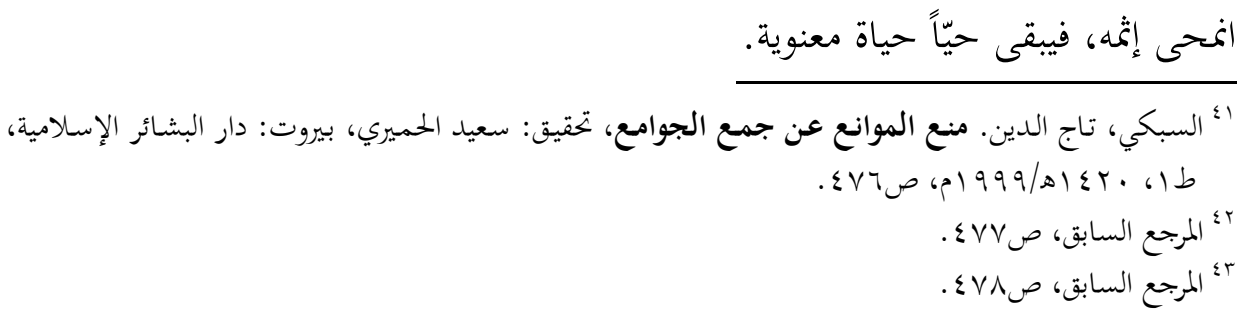




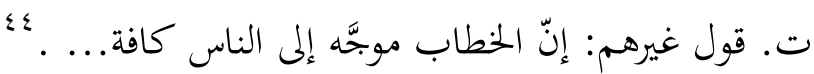

إنّ الخطاب اللغوي ليس فعلاً أحسادي المعنى أو شفافاً في أغلبـه، بـل للسياق دور بنائي في عملية إنتاجه وتأويله. ففي لحظة إنتاجه، يقوم بناؤه على افتراض القائم به قدرةً

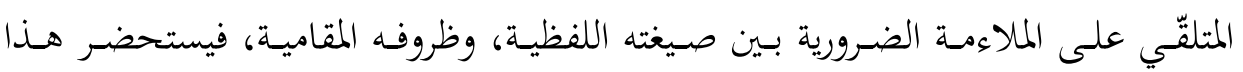

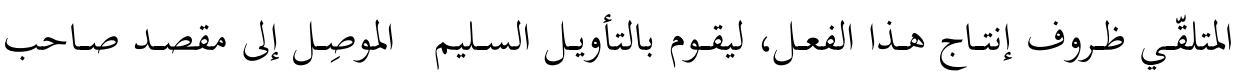
الكام.

إنّ العلاقة التخاطبية التي تقوم بين منتج الكام ومؤوّله تفرض شروطها، ومن أبرزها

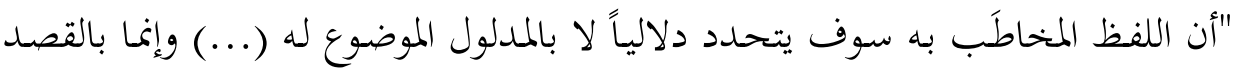

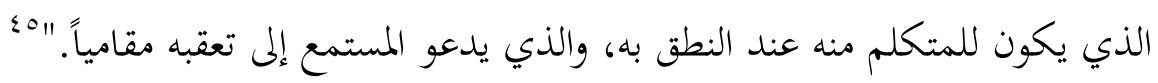
لقد أدرك الأصوليون هذا القانون التخاطبي نظرَاً، ولمسوه اختبـاراً، ولذلك مـا فتئوا

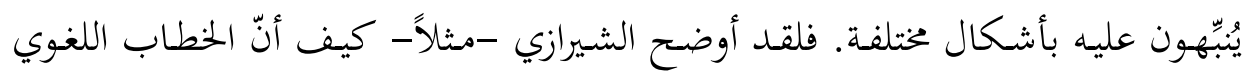

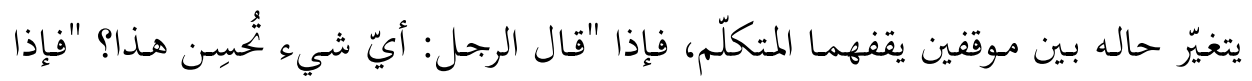

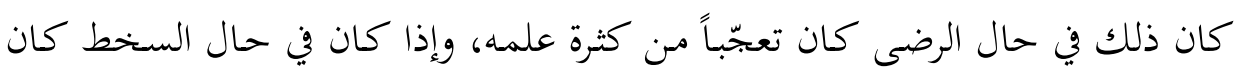

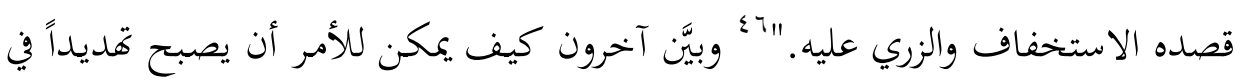

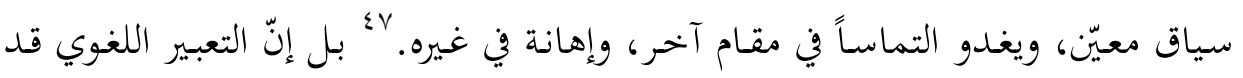

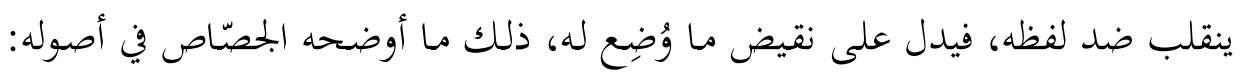

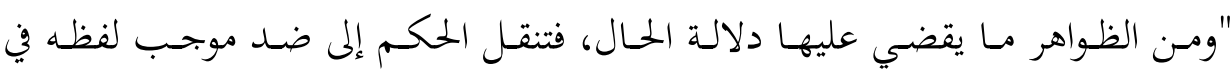

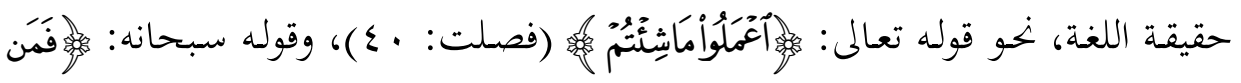
؛؛؛ الإسنوي، جمال الدين. نهاية السول في شرح منهاج الوصول، تحقيق: شعبان محمد إسماعيل، بيروت: دار ابن

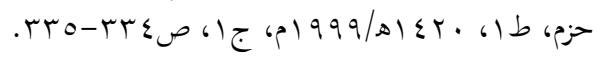

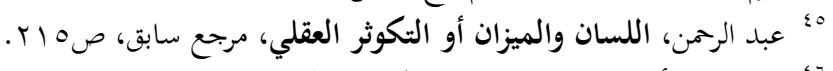

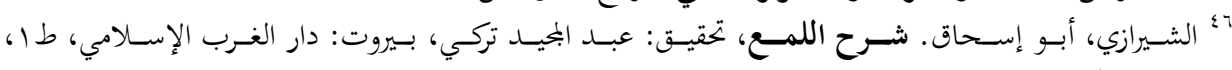

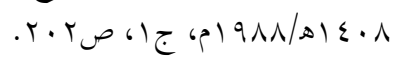

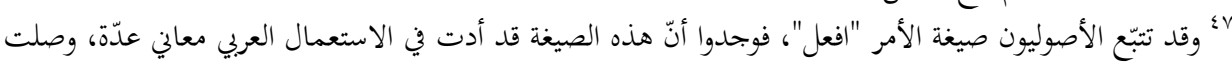

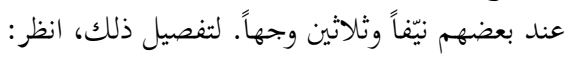
- رمضان، يهيى. القراءة في الخطاب الأصولي: الاستراتيجية والإجراء، الأردن: عالم الكتب الحمديث، طان 


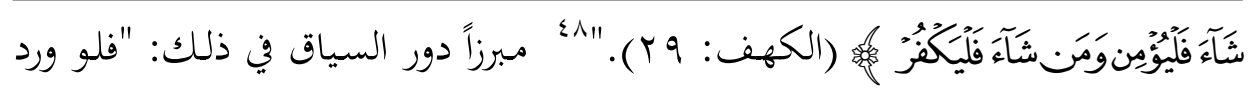

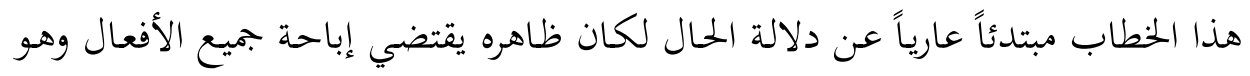

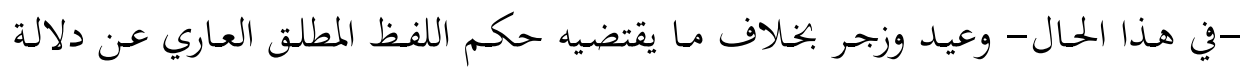

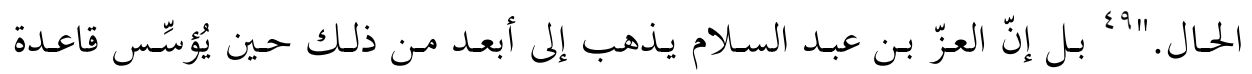

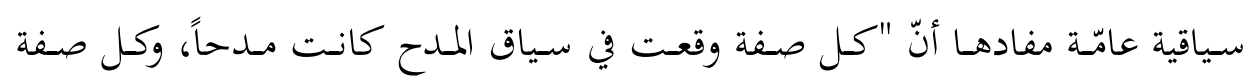

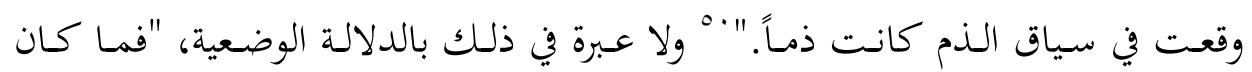

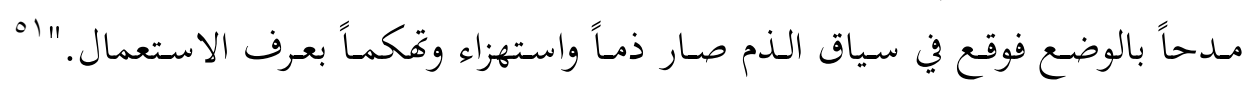

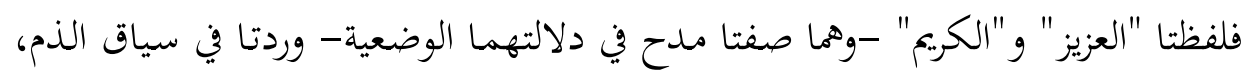

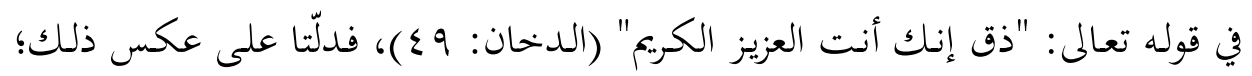

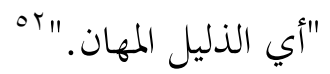

إنّ خصيصة احتمالية الخطاب اللغوي هاته هي مـا جعلت طائفة مـ الأصوليين

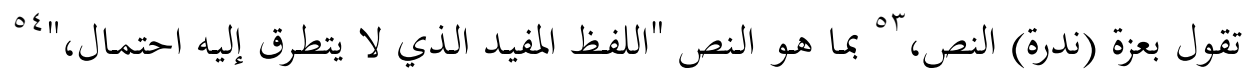

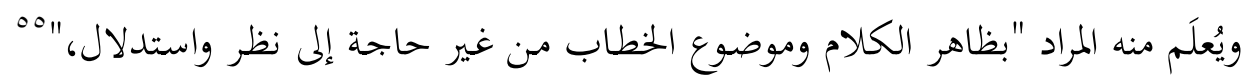

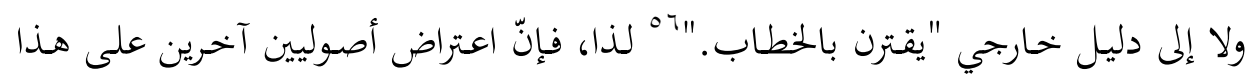

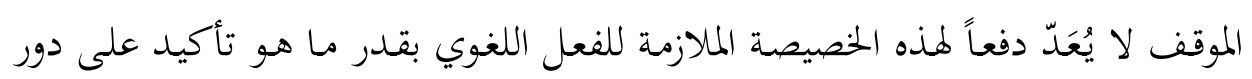

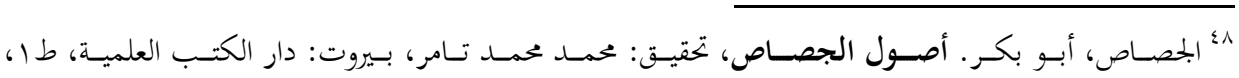

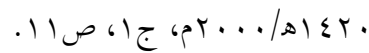

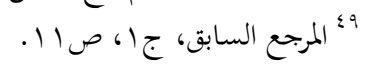
" ابن عبد السلام، عزّ الدين. الإمام في بيان أدلة الأحكام، تحقيق: رضوان غختار بن غربية، بيروت: دار البشائر

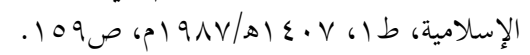

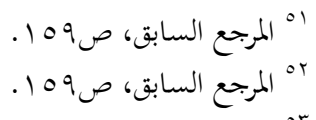

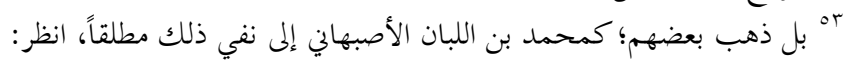

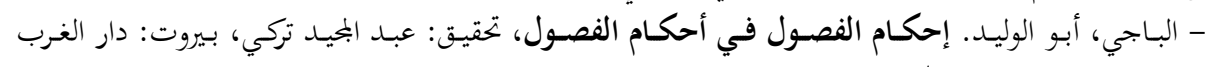

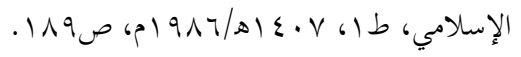

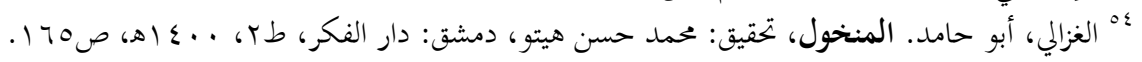

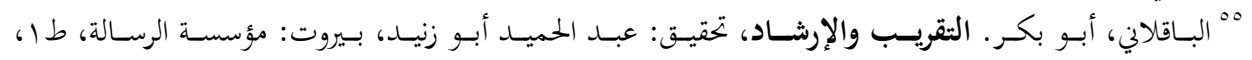
(ل)

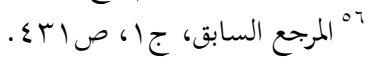




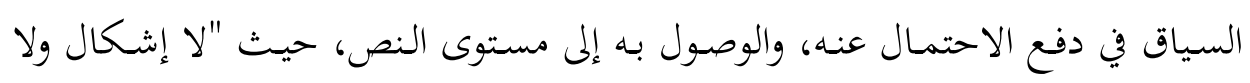

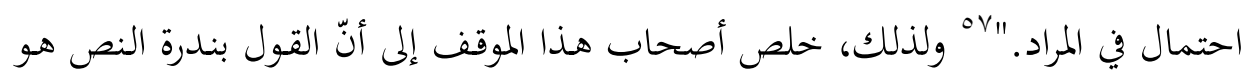

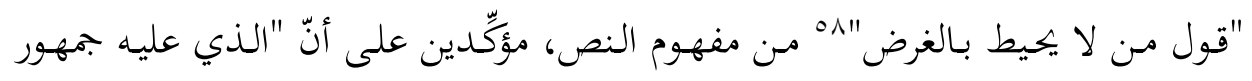

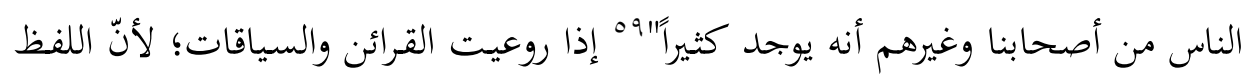

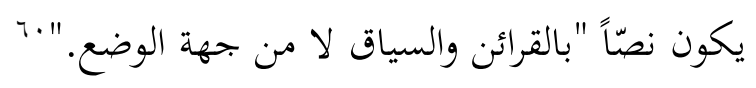

وفي واقع الأمر، يصل الأصوليون المنادون بندرة النص، والقائلون بكثرته، إلى النتيجة

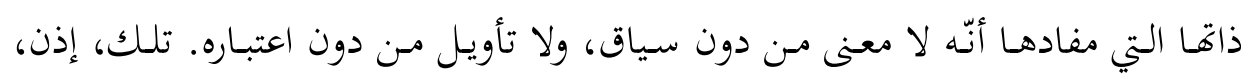

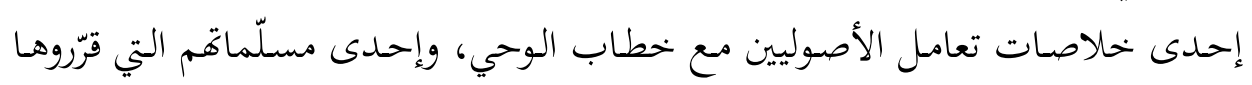
نتيجة تفاعلهم معه: قراءةً، وفهماً، وتأويلاً.

يُذكَر أنّ انتباه الأصوليين للسياق قديم، فمنذ البدايات الأولى لتدوين علم الأصول

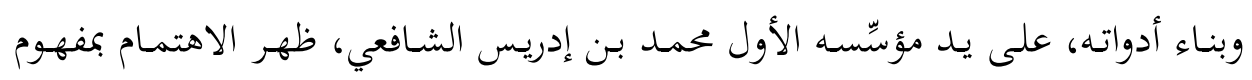

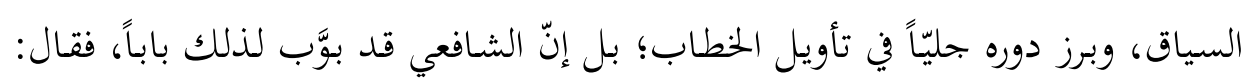

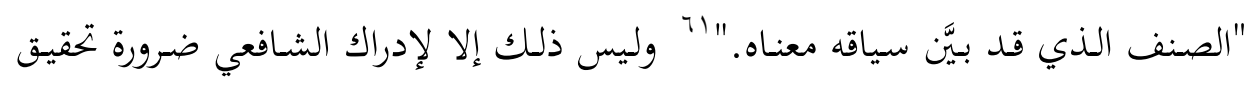

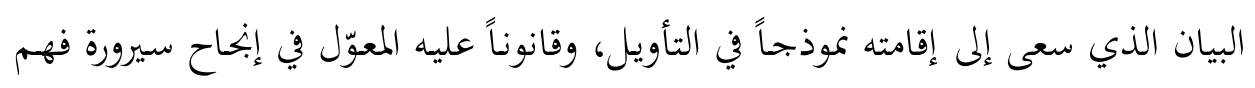
كتاب الله، واستخلاص مقاصد المتكلّم به.

ومنـذ هـذا الفعـل التأسيسي، التقط الأصـوليون هـذه الإشـارة مـن الشـافعي حيـال

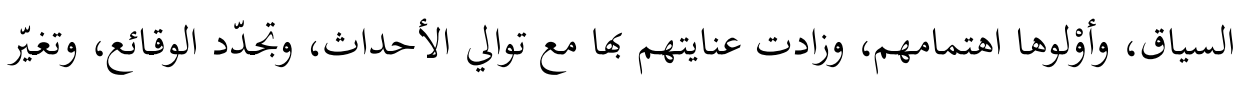

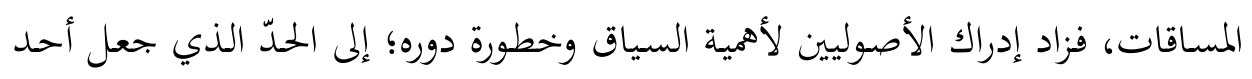

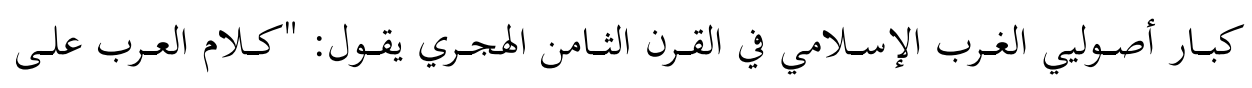

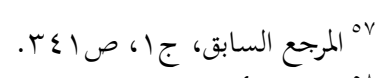
^ما لجويني، أبو المعالي. البرهان في أصول الفقله، تحقيق: عبد العظيم عمود الديب، المنصورة: دار الوفاء، طا،

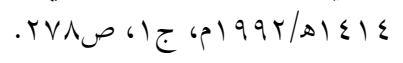

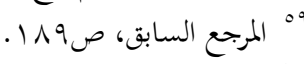

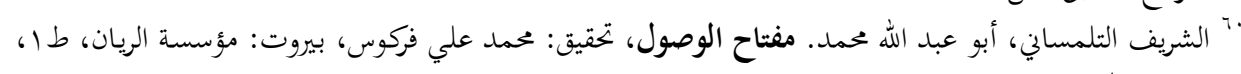

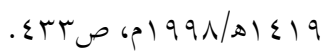
اי الشافعي، محمد بن إدريس. الرسالة، تحقيق: أحمد محمد شاكر، بيروت، دار الكتب العلمية، صبآ. 


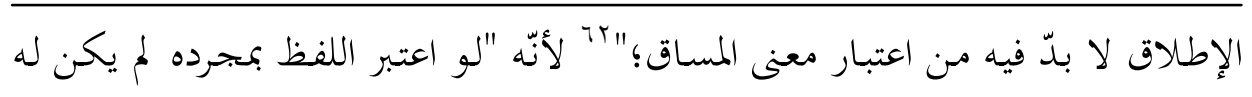

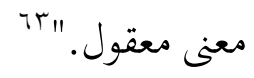

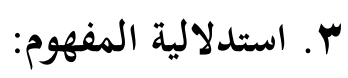

تعرّفنـا - في مـا مضى - أنّه يمكـن الوصول إلى المعنى المعقول حينما يتجـاوز المتلقّي

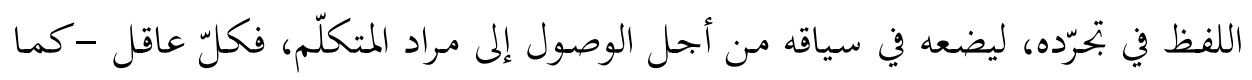

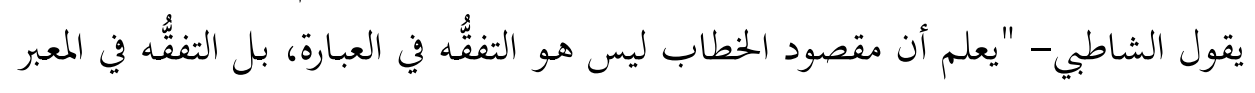

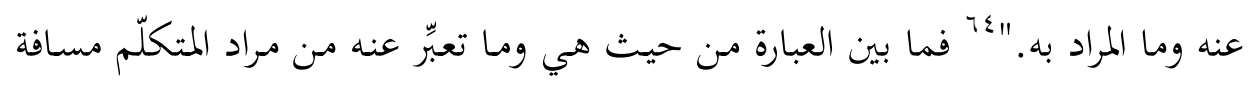

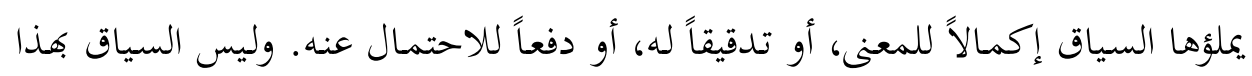

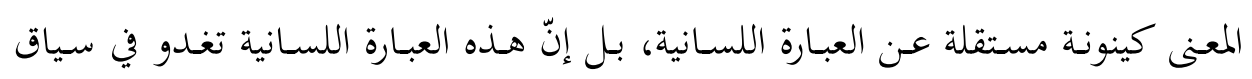
الفهم الكلّي مكوّناً من مكوّناته.

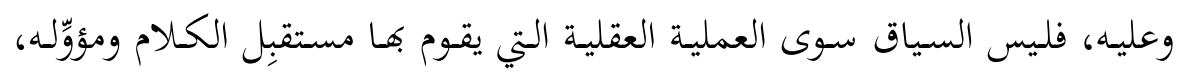

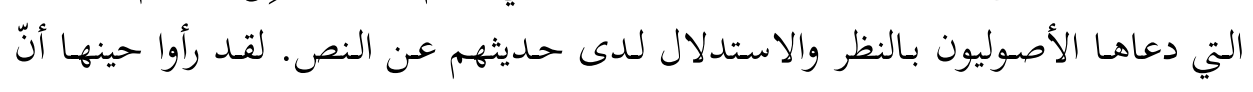

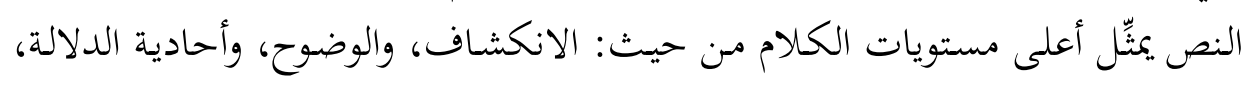

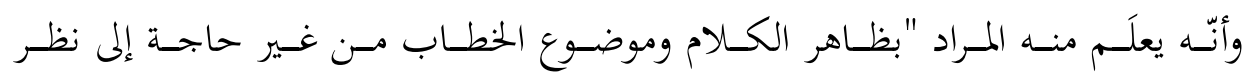

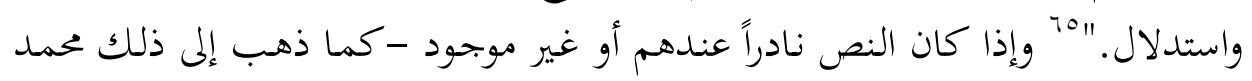

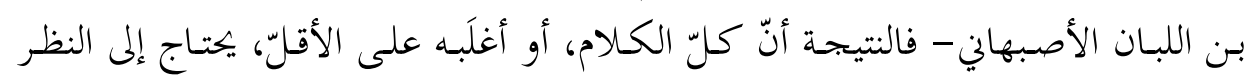

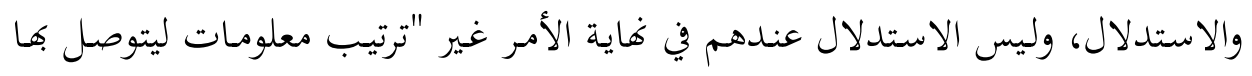

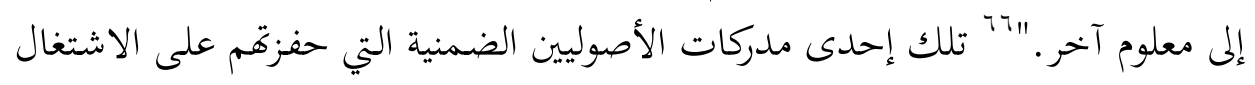

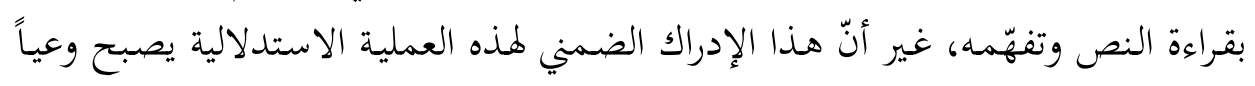
نظريّاً حين يتوقفون عند ما عدّوه مفهوماً.

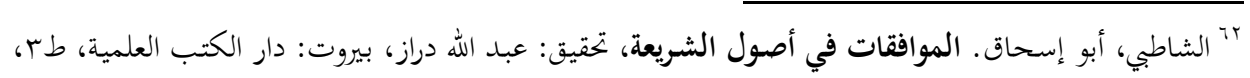

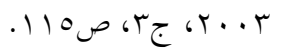

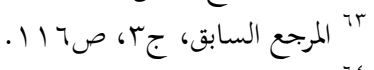

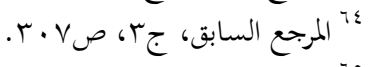

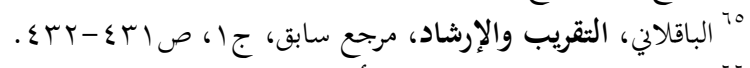

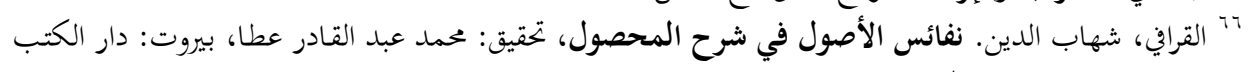

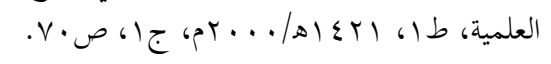


لقد قسّم الأصوليون - كما هو معروف - الكالام إلى منطوق ومفهوم، وعََّّوا الأخير

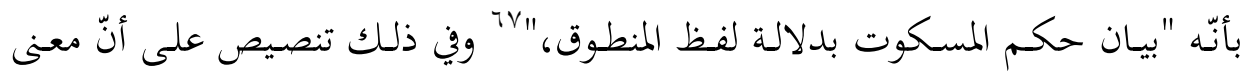

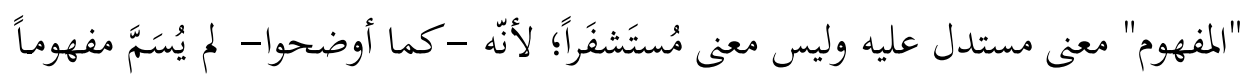

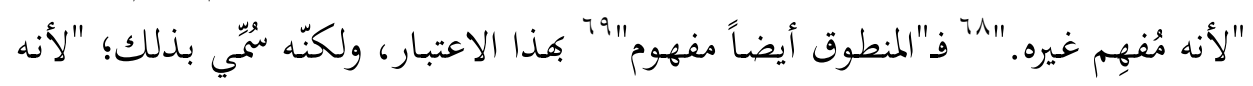

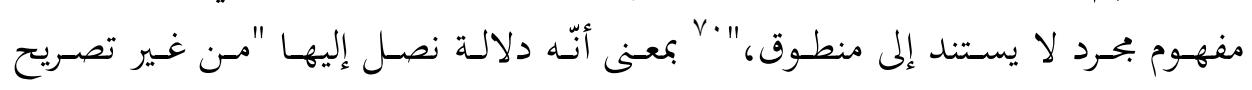

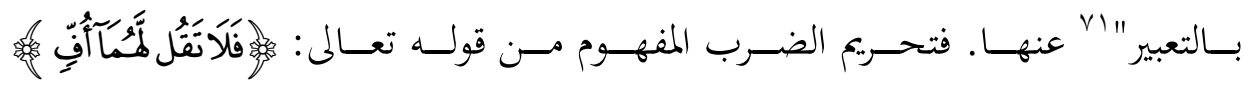

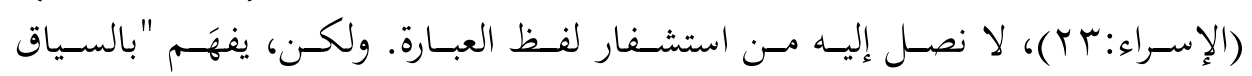
والقرائن.

إنّ المفهوم بهذا الاعتبار هو ثمرة لعملية تحليلية تقوم فيها العبارة المنطوقة، إضافة إلى السياق، بدور بنائي في هذا المتوصَّل إليه، الذي لا تَسنُدُه عبارة صريحة. فالمراد -مثلاًً

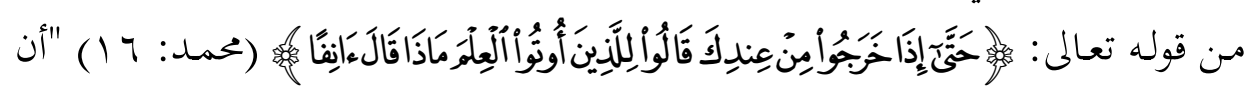

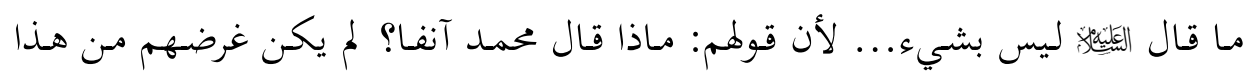
اللفظ استكشاف القول والفحص عن معناه."

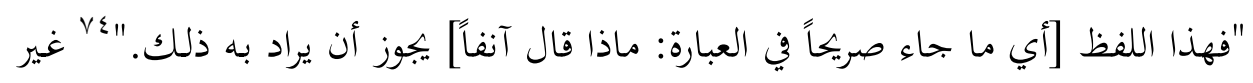

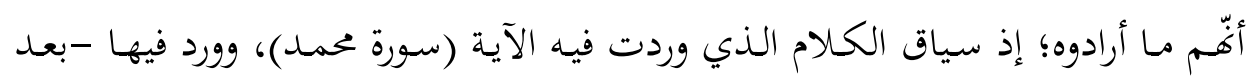

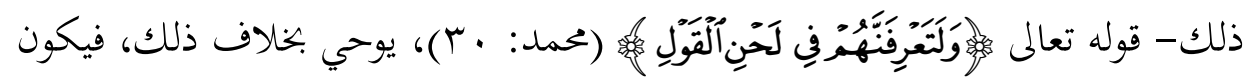

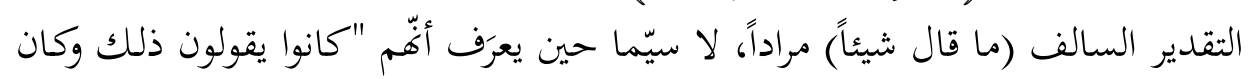

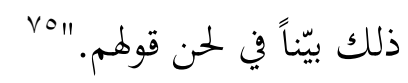

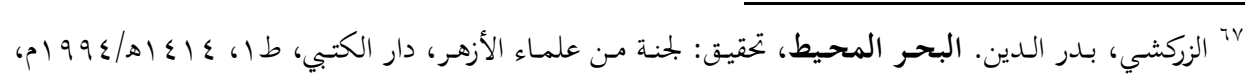

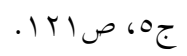
מרי

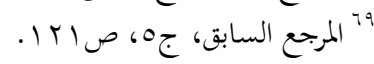

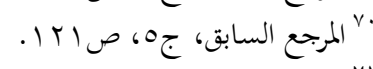

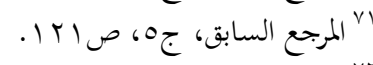

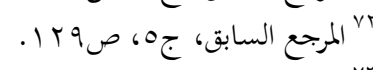

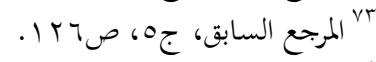

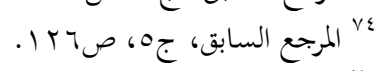

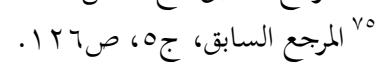




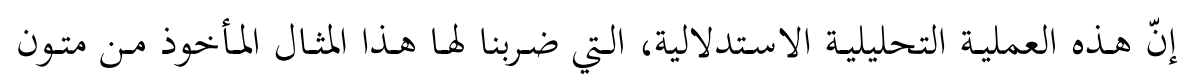

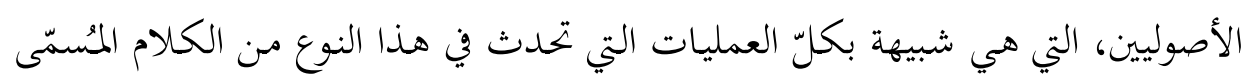

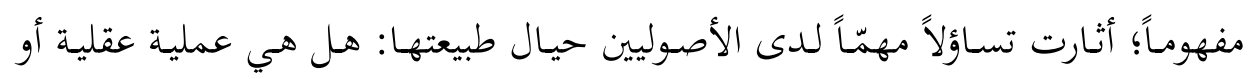

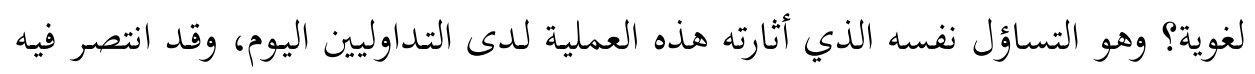
صاحبا نظرية "المناسبة" (سبيربير وولسون) للرأي الأول.

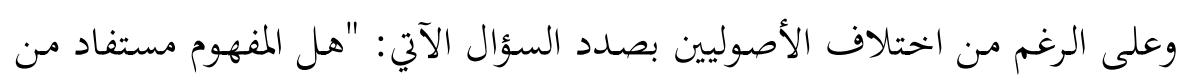

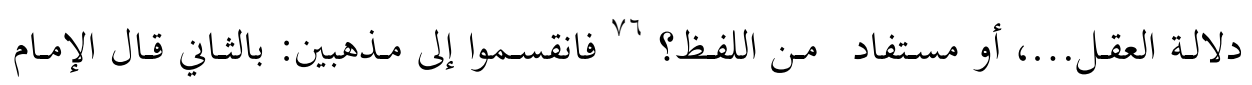

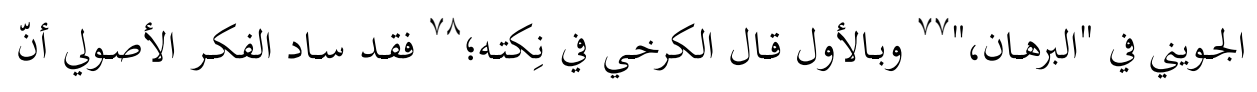

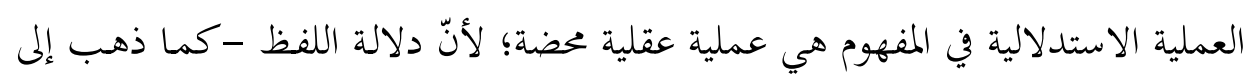

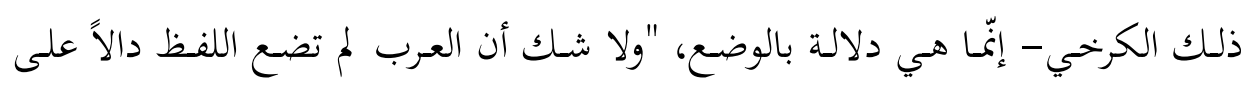
شيء مسكوت عنه.

إذن، سبيل الدلالة في المفهوم هـذا الاعتبـار، هـو الاستدلال العقلي. ومسن تَّهّ فـلا

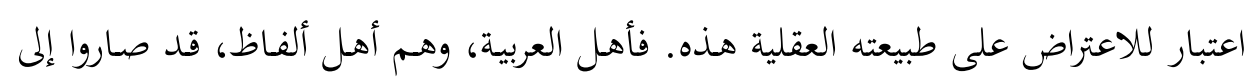

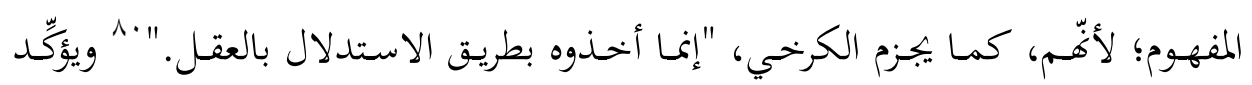

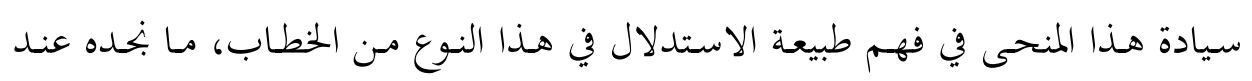

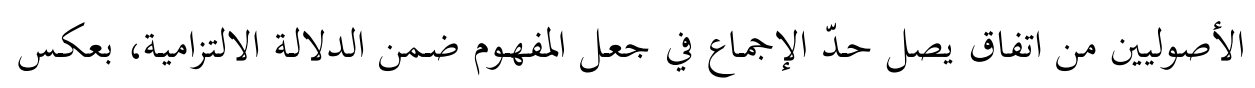

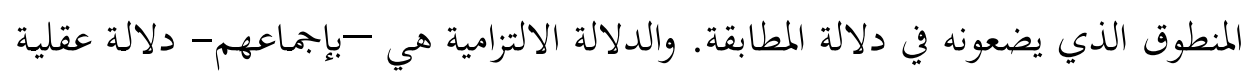

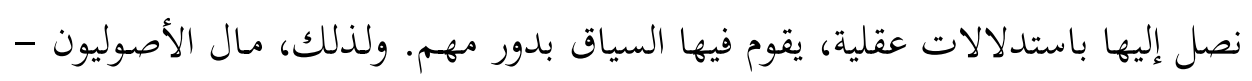

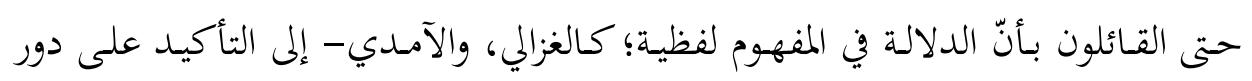

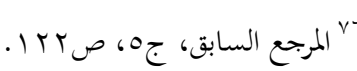

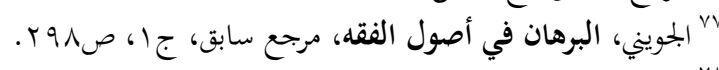

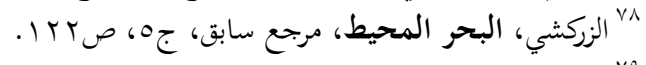

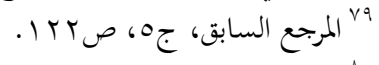

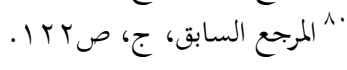




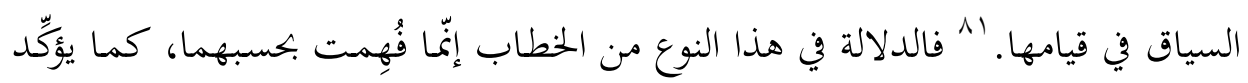

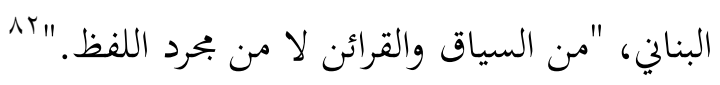

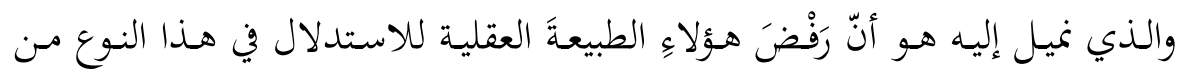

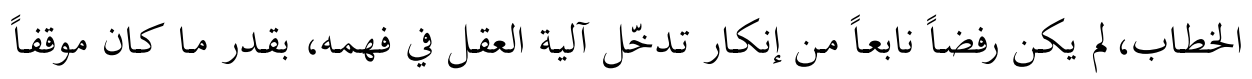

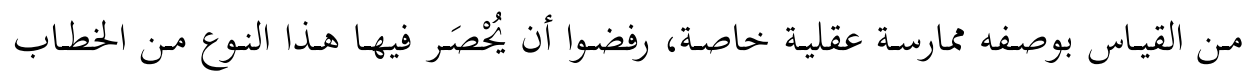

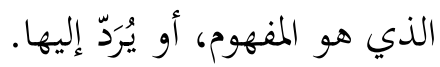

إنّ الممارسة العقلية في المفهوم أعمّ وأوسع من أن تُختزَل في أصل وفرع وعلّة، وإن

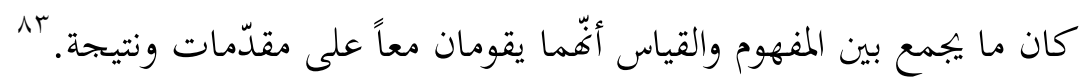

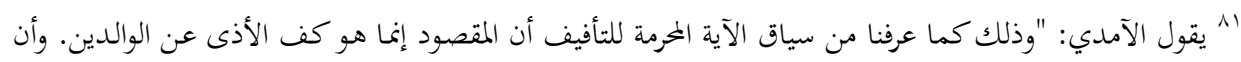

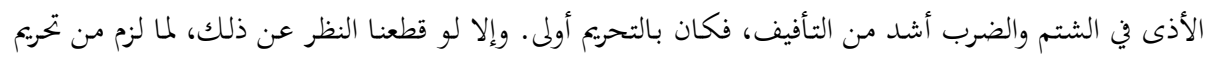

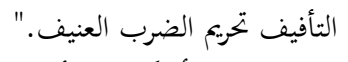
- الآمدي، الأحكام في أصول الأحكام، مرجع سابق، صهو. النظر أيضاً:

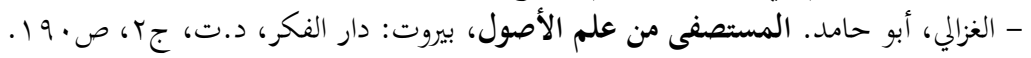

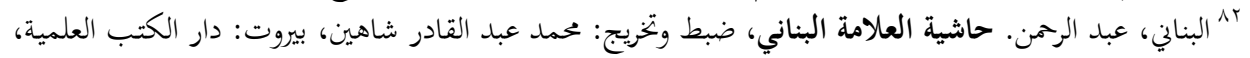

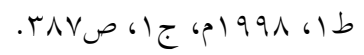

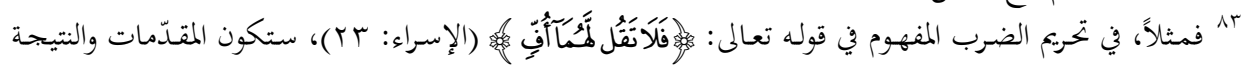

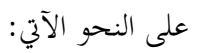

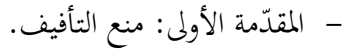

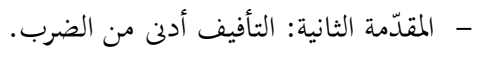

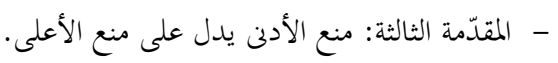

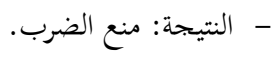
أمّا في ما يخصنّ تخريم الضرب -بوصفه قياساً في الآية نفسها- فتكون المقدّمات والتيجة كما يأني:

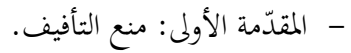

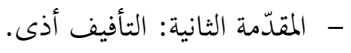

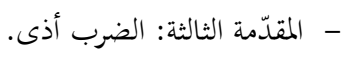

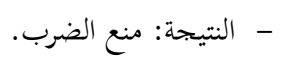

وهذه بناءُ على عدّهم الأمَرَ قياساً أصله التأفيف، وفرعه الضرب، وعلتهه دفع الأذى. فيكون الحكمم منع الضرب. 


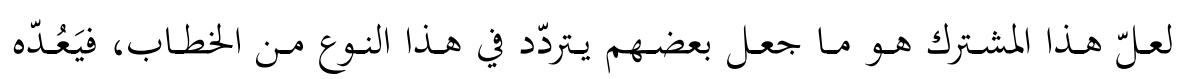

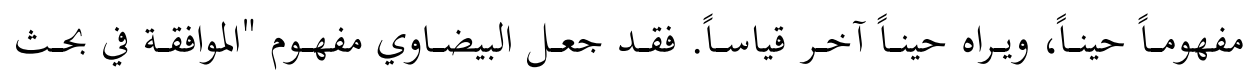

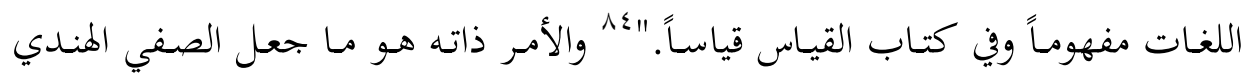

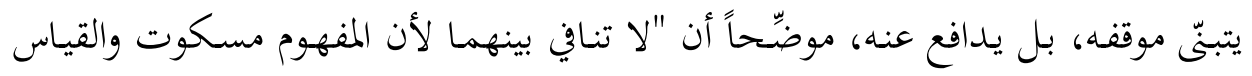

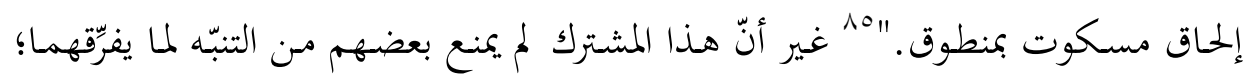

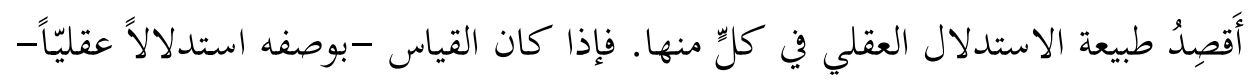

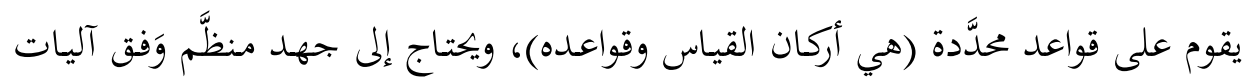

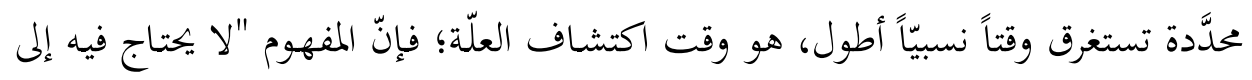

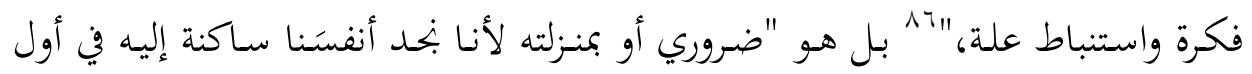

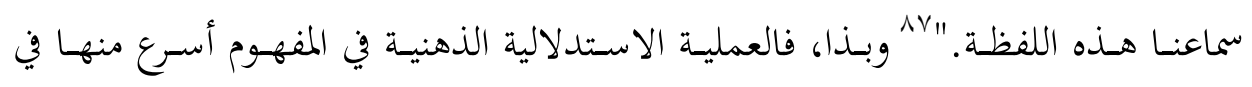

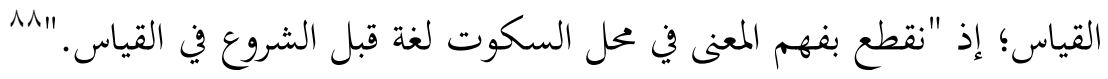

لسنا بحاجة هنا إلى التنويه بأنبّ هذا التمييز بين المفهوم والقياس يقوم على أساس مـا

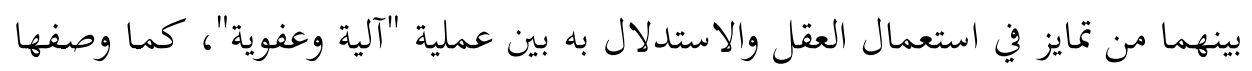

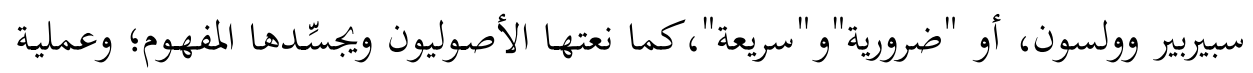
أُخرى صناعية غير عفوية وأقلّ سرعة من سابقتها تتمثَّل في القياس.

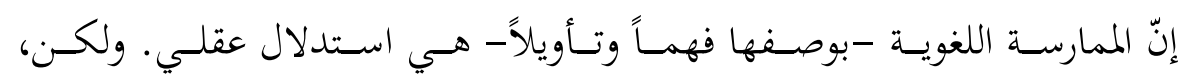

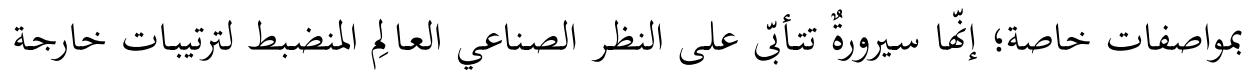
عن طبيعة الفهم اللغوي الآلية العفوية المتميّزة بسرعتها النسبية في معالجة المعلومة. من جانبهما، يرى سبيربير وولسون أنّ الفهم العادي للملفوظات هو فهم لحظي

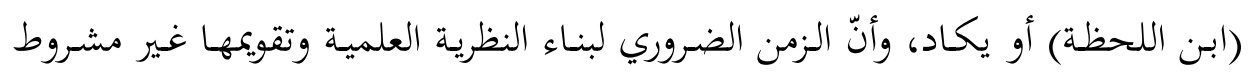

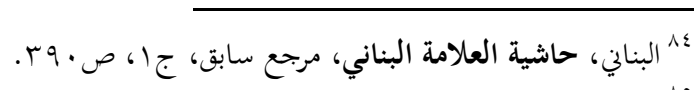

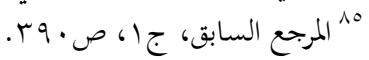

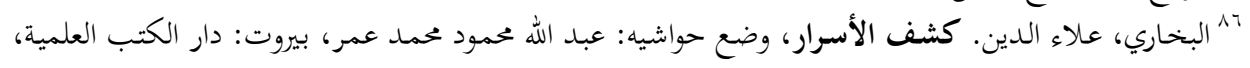

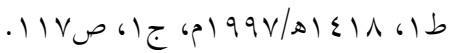

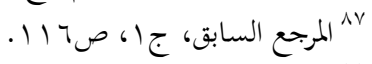

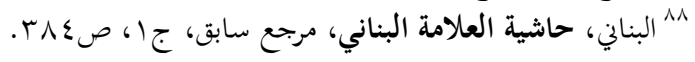




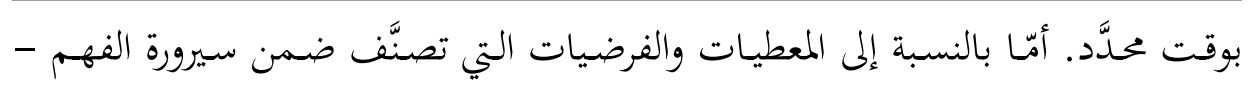

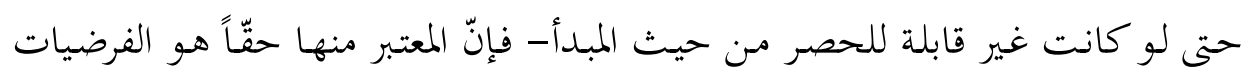

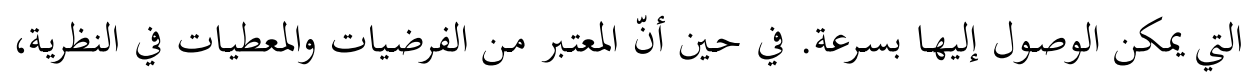

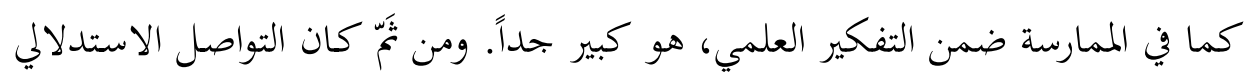

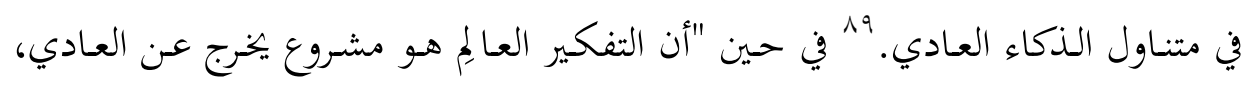

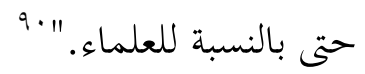

إنّ الطبيعة العقلية باختصار هي جوهر الممارسة الاستدلالية عند الأصوليين؛ حتى

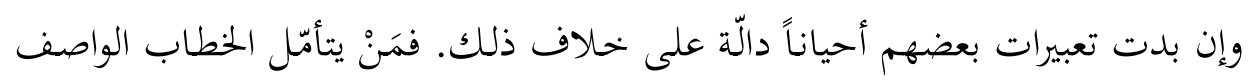

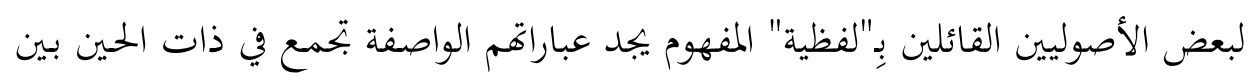

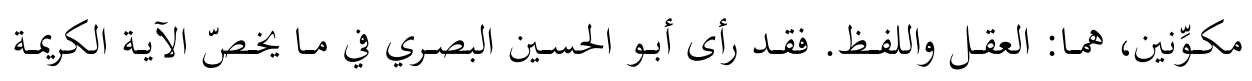

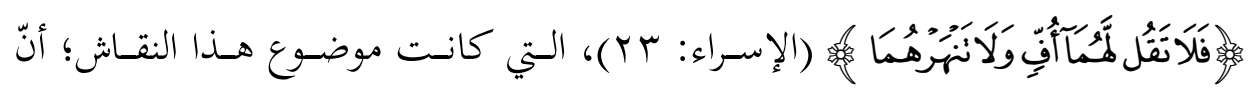

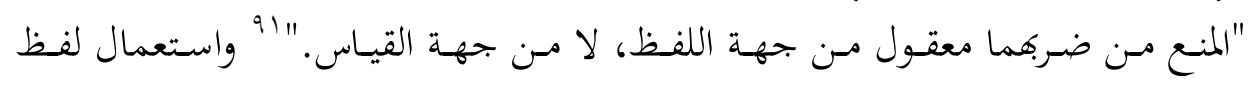

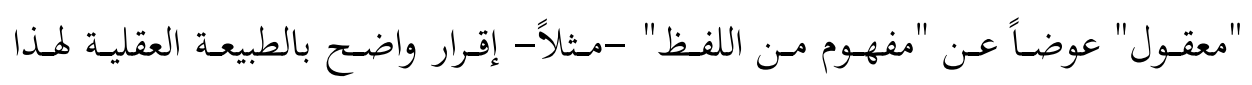

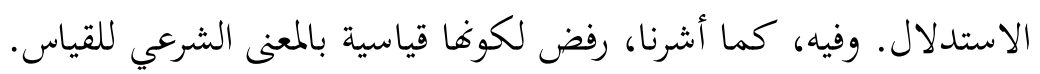

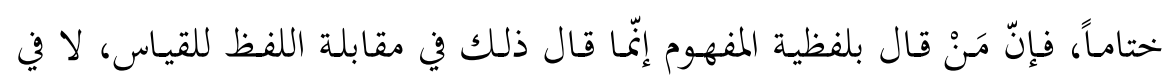

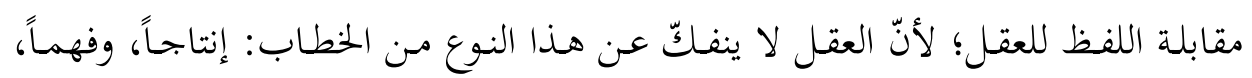
وتأويلاً.

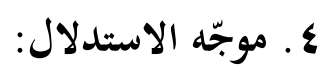

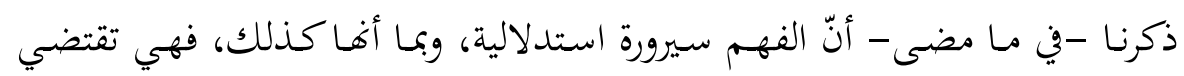

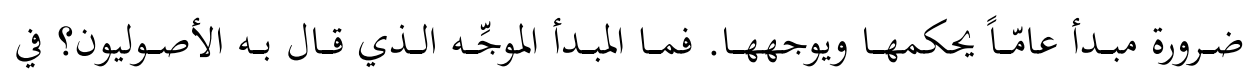

${ }^{89}$ Dan Sperber et Deidere Wilson, La pertinence,communication et cognition, P.105-106.

${ }^{90}$ Ibid, p, 119 .

" البصري، أبو الحسين. المعتمد في أصول الفقه، ضبط وتقديم: خليل الميس، بيروت: دار الكتب العلمية، د.ت، 
الحقيقة، ليس هناك من موجِّه غير ما سمّاه الشاطبي، الذي بنى نظريته في المقاصد، بمقصد

يُعَدّ هذا المبدأ أكثر الصياغات تطوّراً ونضجاً، ضمن مسار طويل لبناء قوانين فهم دلالة خطاب الوحي وصياغة مبادئ تأويلها، وقد تمَّزّ -في فترات منه- بجدل وخحلاف

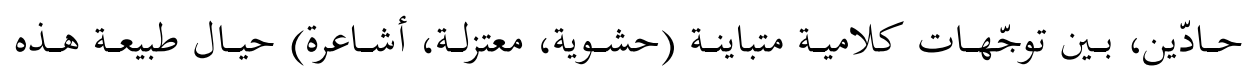

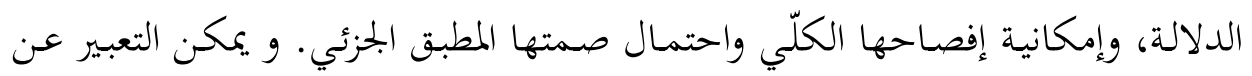

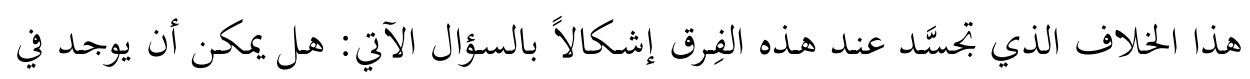
خطاب الوحي ما لا يعني شيئً

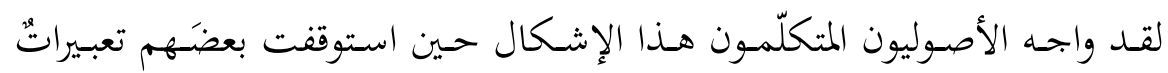

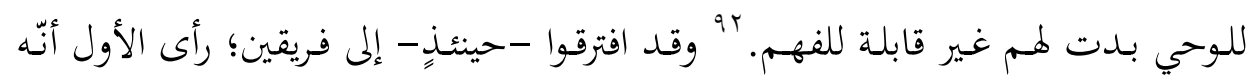

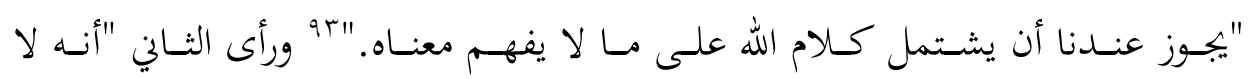

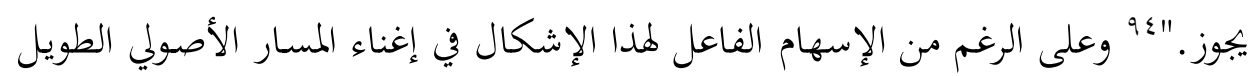
المتعلّق بدلالة خطاب الوحي، فقد طغى عليه الجحل الكلامي، وبقي في كثير من بجليّاته

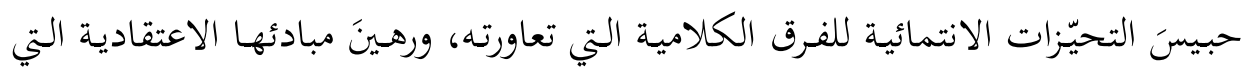

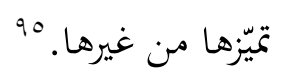

rا هثل أوائل السور. فقد رأت الحشوية "أنه ورد في القرآن قوله تعالى (ألم- المص - كهيعص- طه- حم) وأمثالها، فإنا

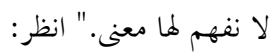

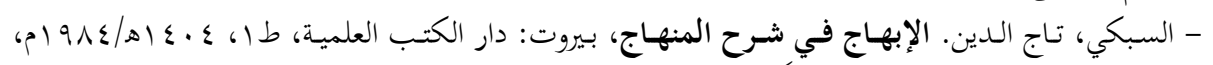

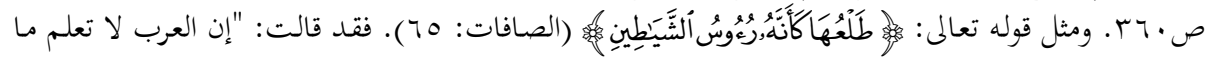

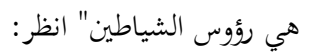

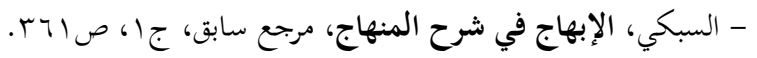

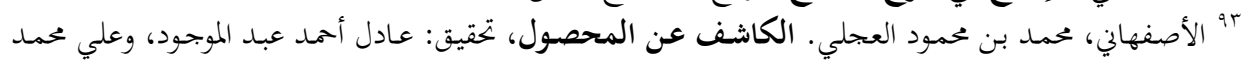

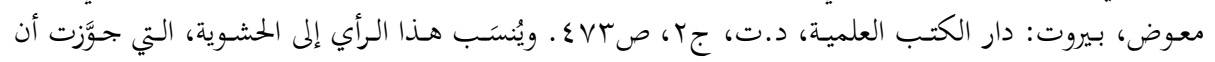

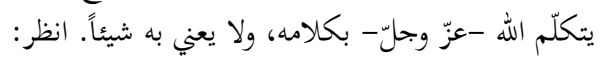

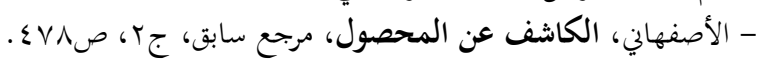

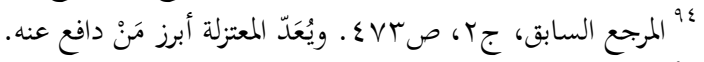

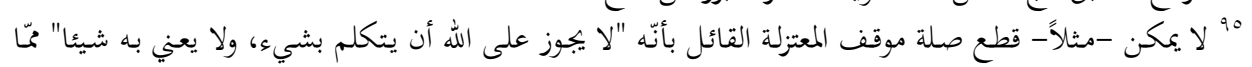

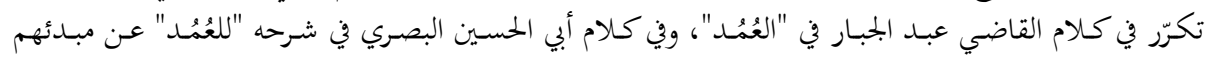


إنّ هذا الجحدل الذي بنحد بعض تفاصيله في ما بقي من تراث المعتزلة الأصولي، هو بمثابة المختبر الذي ستتفاعل فيه كثير من الرؤى الأصولية حيال فهم الخطاب وتأويله،

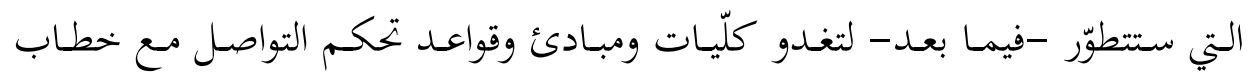

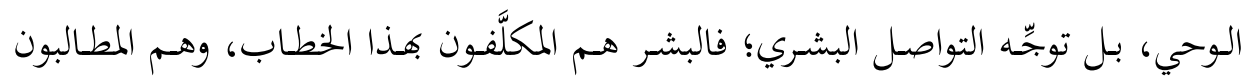

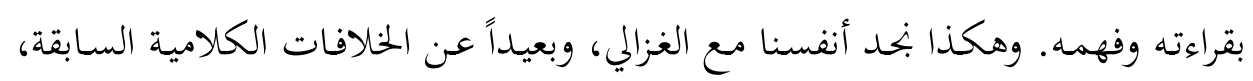

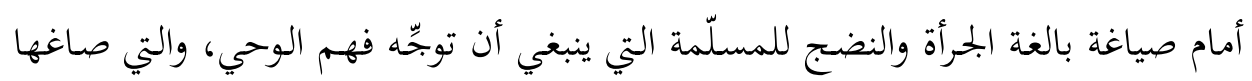

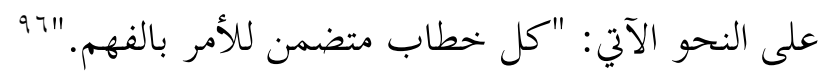
إنّ القـول بـر"استصسحاب الخطـاب للأمـر بـالفهم"، هـو قـول على قـدر كبير مـن

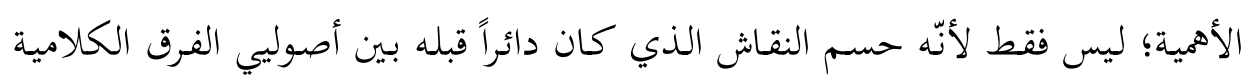

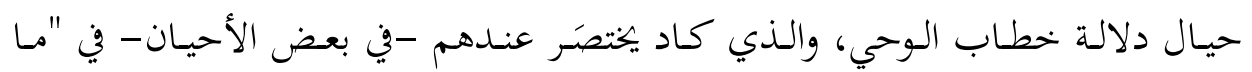

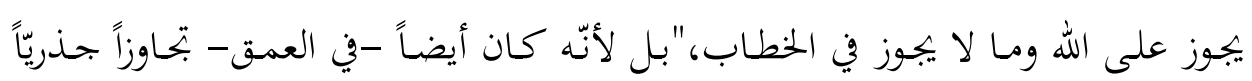
لهذا النقاش، حين أدرك طبيعة الخطاب الجوهرية المتمثّلة في أنّه لا خطاب من دون فهم.

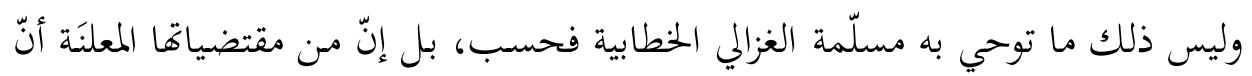
فهم دلالة الخطاب يصبح، بمجرّد حدوث الخطاب، أمراً ينبغي الخضوع له. إذن، أصبحت المسـألة بالنسـبة إلى الغزالي أبعـد مـن أن يكـون فيها الخطـاب محلاًّ

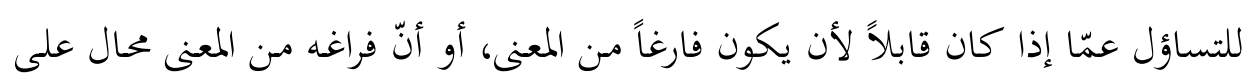
مَنْ أصدره. وبذا، فإنّ المسألة تصاغ مع الغزالي بطريقة مختلفة جذريّاً.

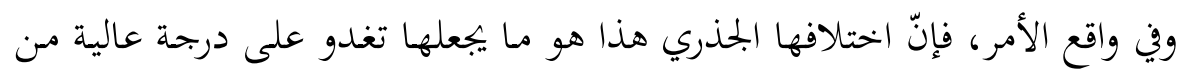

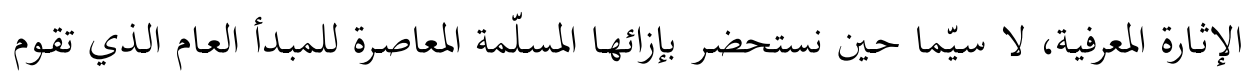
عليه نظرية "المناسبة التداولية"؛ أَي مبدأ المناسبة، التي ينص على بارته أنبّ "كل فعل للتواصل

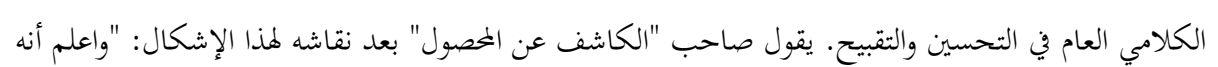

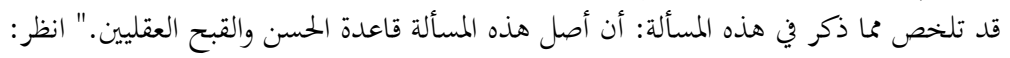

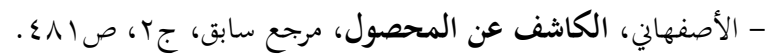

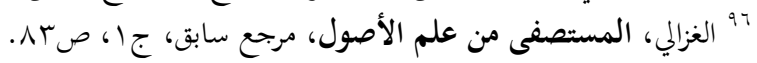




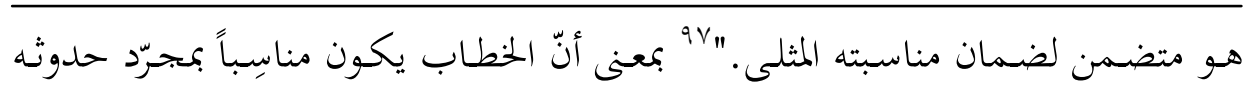

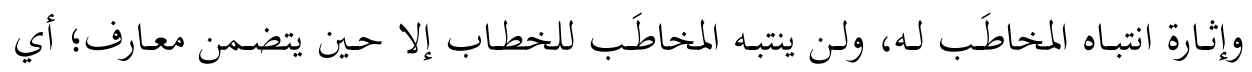

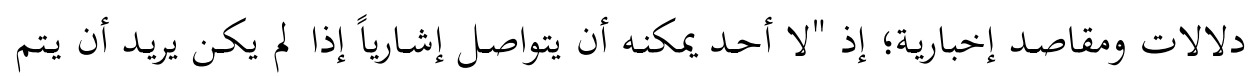

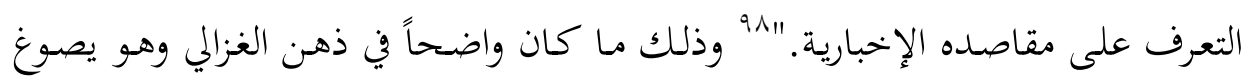
مسلّمته القائلة بِ"استصحاب الخطاب للأمر بالفهم". ويَتبِيَّن ذلك جليّاً بتأكيده أنّ "الله

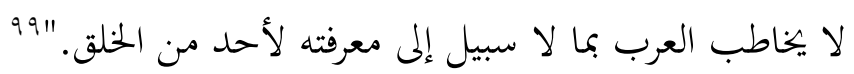

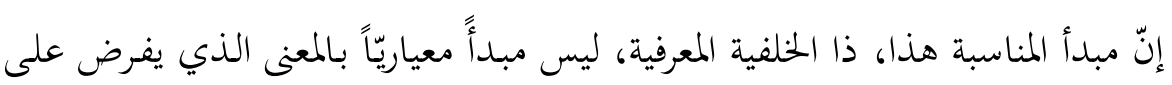

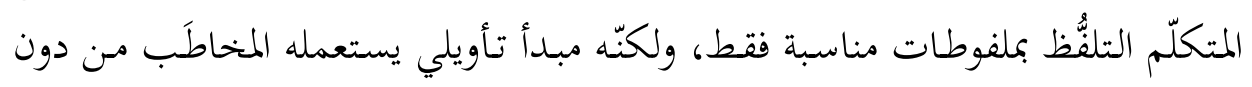

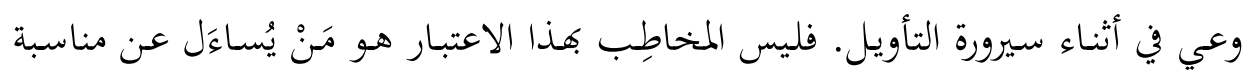

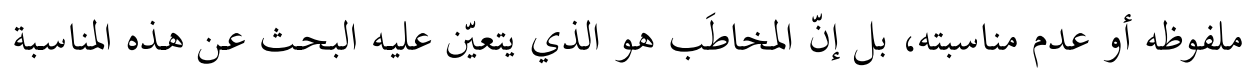
المفترضة في كلّ ملفوظ أثنار انتباهه فتلقّاه.

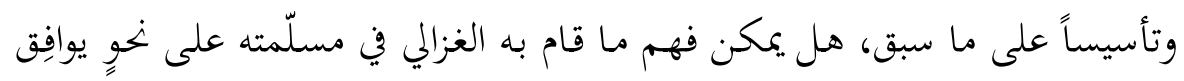

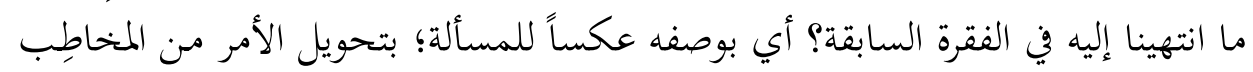

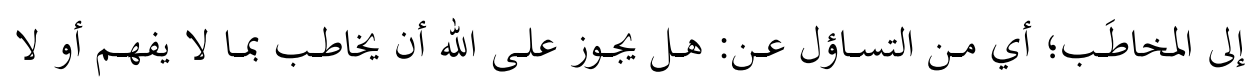

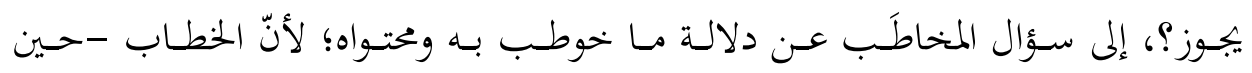
يصدر - لا يحمل في ذاته ضمان مناسبته فحسب - كما ذهبت إلى ذلك ذلك نظرية المناسبة

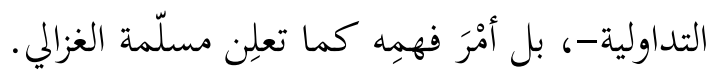

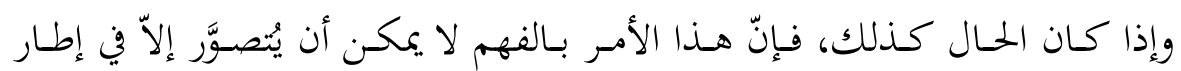

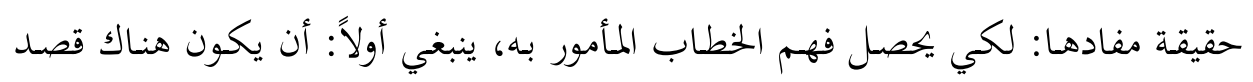

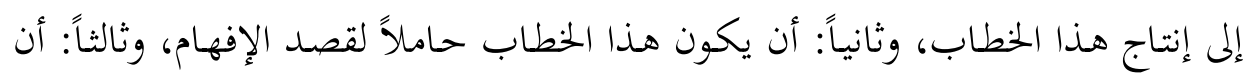
يكون حاملاً لمحتوى قابل للفهم وهو المتجلي في اللغة.

${ }^{97}$ Jacques Moeschler, Théorie pragmatique et pragmatique conversationnelle, Armand Colin /Mason,1996,p.30.

${ }^{98}$ Dan Sperber et Deidere Wilson, La pertinence,communication et cognition, P.1.०.

$$
\text { 99 الغزالي، المستصفى من علم الأصول، مرجع سابق، ج)، ص7 + 1. }
$$




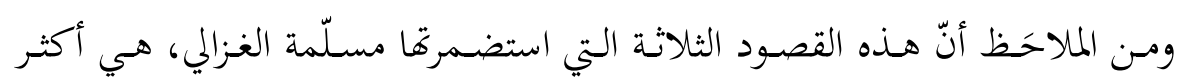

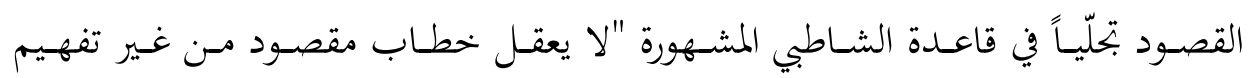

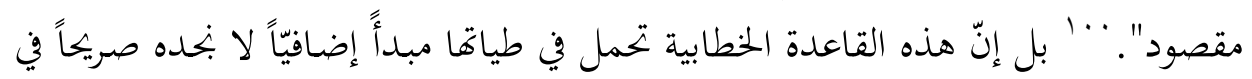

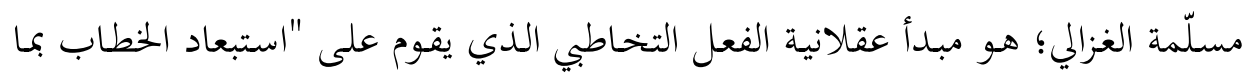

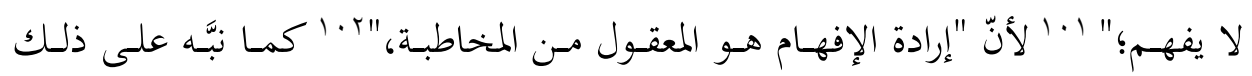

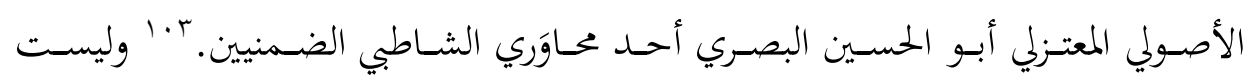

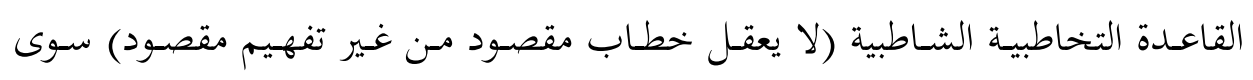

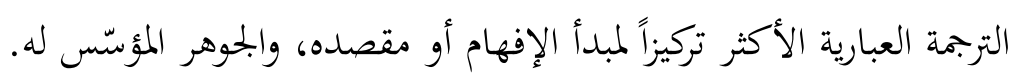

إذن، يتميّز مبدأ (أو مقصد) الإفهام بطابعه العقلاني، ــ الذي يجعل لكله خطاب

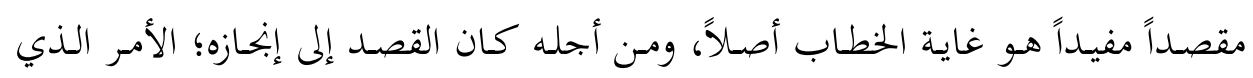

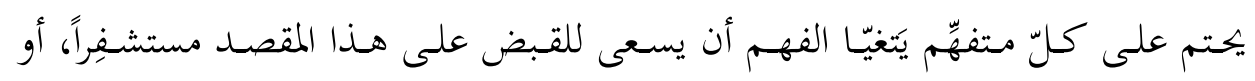

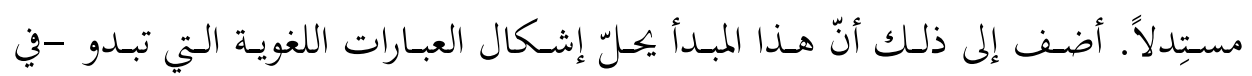

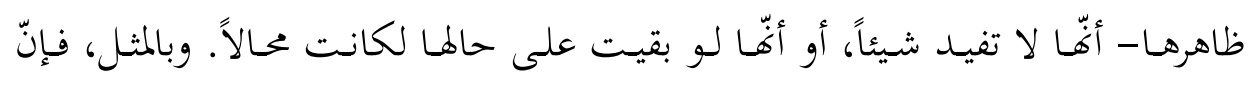

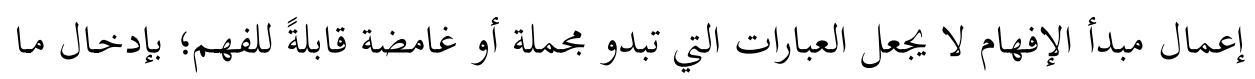

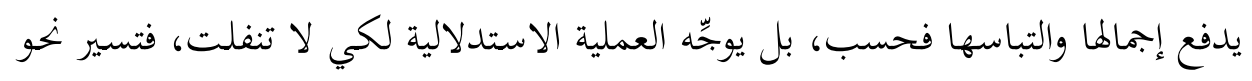

$$
\begin{aligned}
& \text { ما لم يقصده صاحب الخطاب من خطابه. }
\end{aligned}
$$

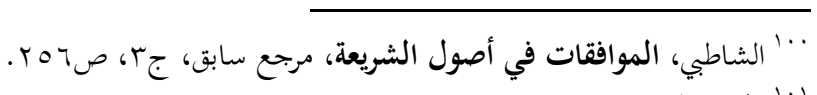

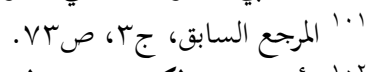

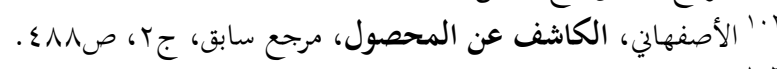

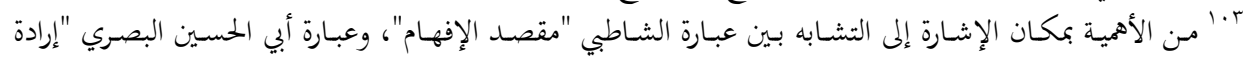

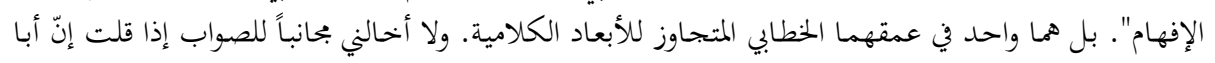

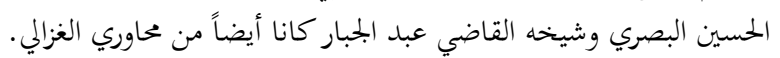

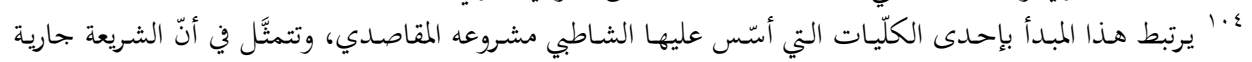

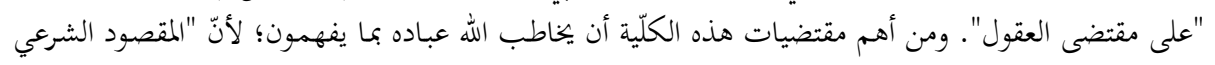

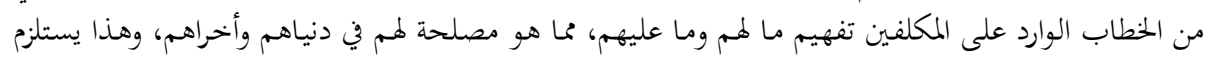

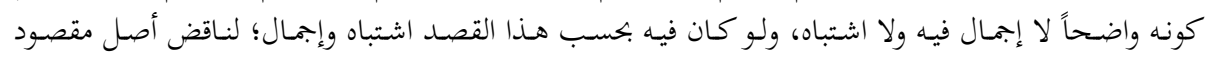

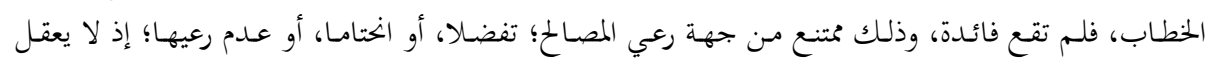

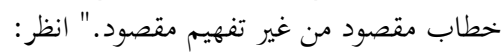

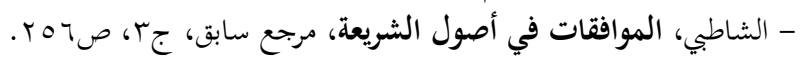




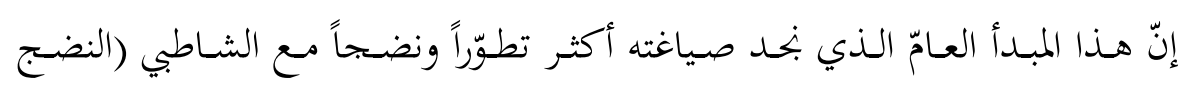
والتطوّر المتجاوزان للإشكالات الكامية المخالفة لطبيعة الخطاب، والوعي بجوهر العملية

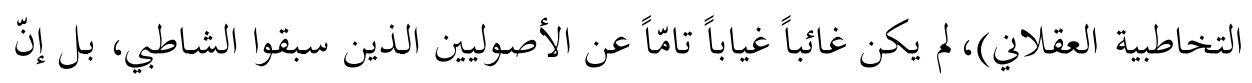

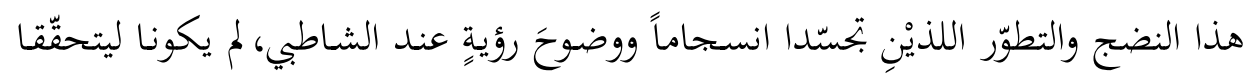

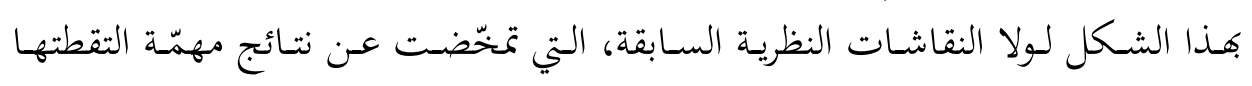

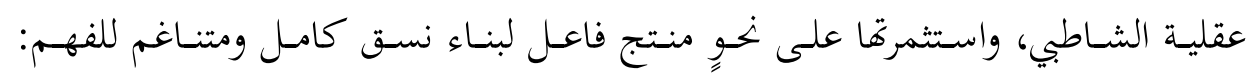
مسلّمات، وآليات، وحدوداً.

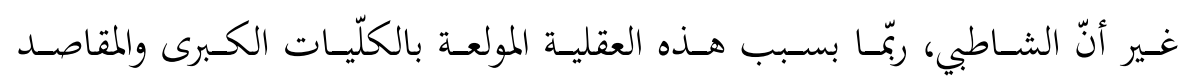

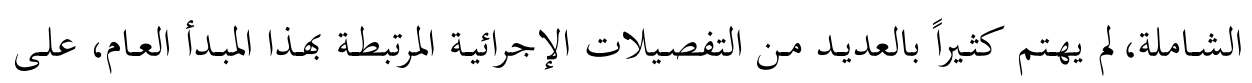

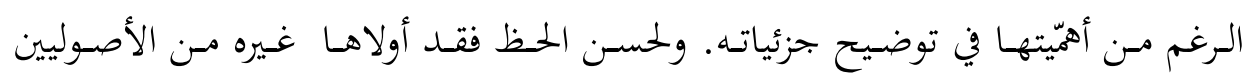

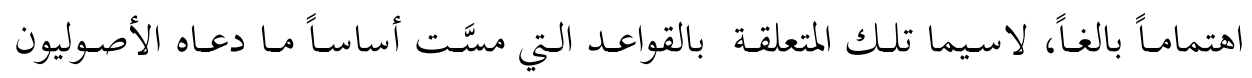

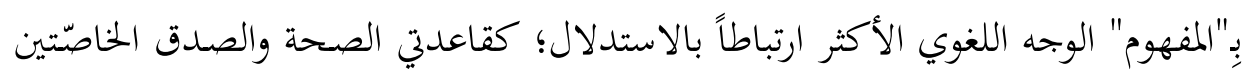

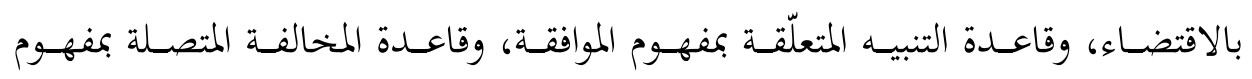
المخالفة.

خاتمة:

حاولت هذه المقاربة بيان وعي الأصوليين بدور الاستدلال في الفهم والتأويل، وإبراز

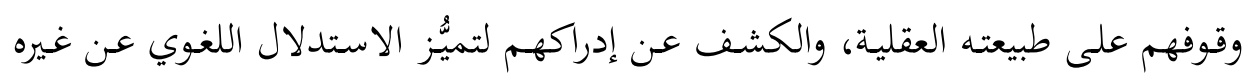

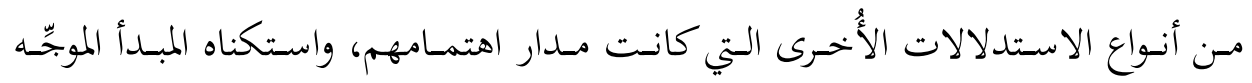

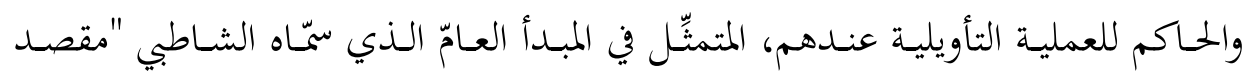

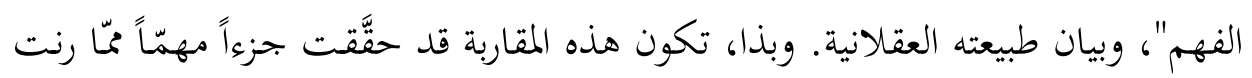
إليه.

إنّ إثارة الانتبـاه للاستـلال اللغوي عند الأصسوليين، بُحلمي طبيعة النموذج التـأويلي الذي بنوه بالكشف عن مكوّّن مهمّ من مكوِّي العملية التأويلية لديهم، وتضع الإبحاز 


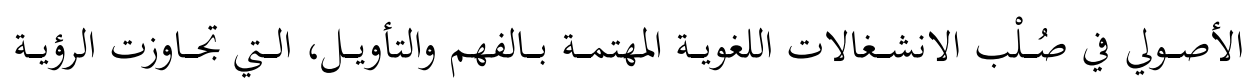
الشفرية التي هيمنت على الفكر اللغوي المعاصر مدّة طويلة من الزمن. غير أنّه ينبغي التنبيه على أنّ الاهتمام بالاستدلال -بوصفه الشَّقّ المكمّل للشفرةلا ينبغي أن يكون على حساب شِقّه الآخر؛ وإن كان يمنح السياق أو المقام دوراً مهمّاً.

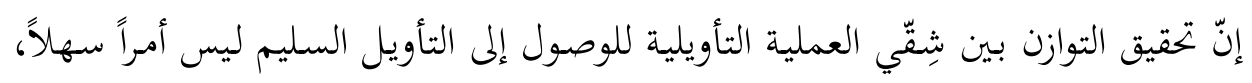

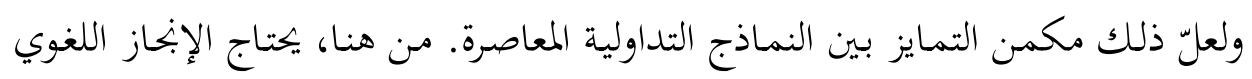

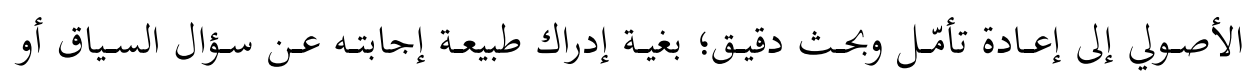

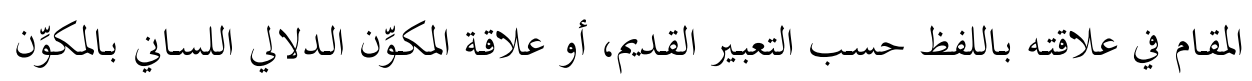

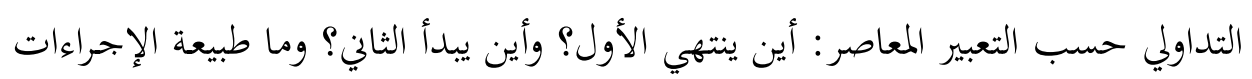

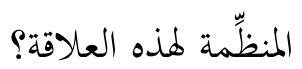

لا شكّ في أنّ جهوداً مضنية قد بُذِلت في هذا الإطار، غير أنّا ما تزال غير كافية

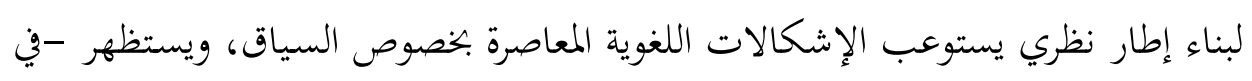

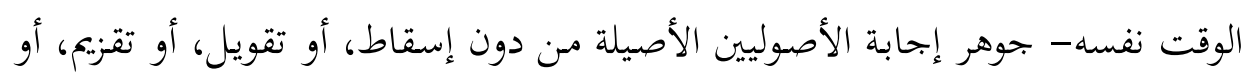

